\title{
Antoni Cellers i el seu entorn: notes sobre arquitectura religiosa vuitcentista ${ }^{1}$
}

\author{
Maria Garganté Llanes \\ Universitat Autònoma de Barcelona \\ mgargante@uoc.edu
}

RESUM

L'objectiu del present article és parlar de l'arquitectura religiosa catalana de la primera meitat del segle xIX i la vinculació que tenia amb l'estètica neoclàssica, utilitzant com a eix central la figura de l'arquitecte nascut a Lleida Antoni Cellers i Azcona, acadèmic pensionat a Roma i primer director de l'Escola d'Arquitectura de la Llotja. El seu edifici religiós més rellevant és l'església dels escolapis de Sabadell, si bé realitzà uns altres projectes a Barcelona i Lleida. L'estudi que presentem pretén visibilitzar els altres exemples de l'arquitectura religiosa produïda al nostre país per uns altres mestres d'obres i arquitectes acadèmics, com ara Francesc Renart i Arús, Francesc Vila o Josep Mestres, i mostrar que el neoclassicisme, si bé va ser adoptat tardanament a Catalunya, s'hi manifestà profusament sota influències neopal-ladianes durant mig segle.

Paraules clau:

arquitectura religiosa, academicisme, neoclassicisme, neopal-ladianisme.

\section{Abstract}

The aim of this article is to present some examples of religious architecture of the first half of the Igth century in Catalonia and his linking with the neoclassical aesthetics, having as a central axis the figure of the architect born in Lleida Antoni Cellers Azcona, academician pensioned in Rome and first director of the School of Architecture in Barcelona. His most relevant religious building is the church of the Escolapis in Sabadell, although he carried out other projects in Barcelona and Lleida. The study that we present intends to make visible the other examples of the religious architecture produced to our country by other master builders and academic architects, like Francesc Renart i Arús, Francesc Vila or Josep Mestres, showing than the neoclassicism, although adopted in a late way in Catalonia, is manifested under neopalladian influences during half a century.

Key words:

religious architecture, academicism, neoclassicism, neopalladianism. 
2. Les sigles utilitzades en aquest article són les següents: ADS (Arxiu Diocesà de Solsona), AHAT (Arxiu Històric Arxidiocesà de Tarragona), $\mathrm{AHN}$ (Archivo Histórico Nacional), BC (Biblioteca de Catalunya), RABASF (Real Academia de Bellas Artes de San Fernando) i RABASJ (Reial Acadèmia de Belles Arts de Sant Jordi).
$\mathrm{L}$ 'interès per l'arquitectura religiosa del segle xIx està marcat avui en dia per una certa actitud de rebuig $i$ indiferència, ja que, a part que no coincideix amb el gust arquitectònic actual, la poca antiguitat que té li resta l'atractiu que encara se li pot trobar a una església de l'època del barroc - sempre tenint en compte que la revalorització de l'art barroc és un fenomen relativament recent. A més, massa sovint s'ha reduit el neoclassicisme en l'arquitectura catalana del segle xix a les figures que hom ha volgut antagòniques - per bé que complementàries - d'Antoni Cellers i Antonio Ginesi, acompanyats de les que en serien les realitzacions més paradigmàtiques: l'església dels escolapis de Sabadell, en el cas de Cellers, i el cementiri del Poble Nou, en el cas d'Antonio Ginesi - si bé podem assenyalar clars epígons d'aquestes obres en el mateix projecte de Cellers per a la irrealitzada església del Vilosell o fins i tot en d'altres exemples més tardans de capelles i espais com ara la capella del Cementiri Vell de Terrassa o la porta d'ingrés al cementiri de Solsona, que recullen alguns aspectes de l'obra de Ginesi, com ara la combinació de motius grecs i neoegipcis ${ }^{2}$.

El nostre objectiu és posar de manifest que la voluntat classicista al segle XIX en l'arquitectura religiosa no fou pas un fet aillat - sí, en canvi, mal conegut -, ja que el classicisme acadèmic (encara tenim certa recança a qualificar-lo obertament de neoclasicisme) va imposar-se amb força en alguns temples de nova planta que varen construir-se sobretot durant la primera meitat del segle, mentre que, a partir del segon terç, aquesta classicitat es veurà dissolta $\mathrm{i}$ apartada per una altra tendència que s'imposa de forma gairebé implacable: el neomedievalisme. Exemple d'aquest canvi és la continuació de l'església de Sant Feliu de Llobregat, que, d'un primer projecte d'arrels neoclàssiques, obra de Francesc Renart i Arús, passa a conclou- re's segons el projecte neoromànic de Josep Simó i Fontcuberta - qui, al seu torn, també projectarà la magnífica i avui desapareguda església neogòtica de Sant Martí del Clot.

Aquest reduccionisme també és provocat pel fet que algunes de les realitzacions que haurien pogut esdevenir emblemàtiques d'aquesta arquitectura de regust marcadament classicista del primer terç del segle XIx no es conserven. Els casos més flagrants d'aquesta desaparició els tenim a les esglésies de Sants i de Molins de Rei, mentre que també trobem nombrosos exemples de projectes irrealitzats, com ara l'esmentada església del Vilosell (a la lleidatana comarca de les Garrigues) o la de Sant Feliu de Llobregat, mentre que a Sant Andreu del Palomar també es deixaran de banda les intencions classicistes de Pere Serra i Bosch i Josep Mas i Vila per acabar abraçant el projecte neobizantí de Domènech i Estapà.

\section{Conseqüències de la Guerra del Francès i creació de l'Escola d'Arquitectura de la Llotja de Barcelona}

Si el començament del segle xviII estava marcat per la Guerra de Successió, els inicis del segle XIX els trobem condicionats per la guerra resultant de la invasió napoleònica, l'anomenada Guerra del Francès, que suposarà una nova sotragada per al territori que també va comportar desafortunades conseqüències per al patrimoni arquitectònic. Així doncs, el fons documental procedent de la família de mestres d'obres Renart ens proporciona diverses informacions significatives al respecte, com ara el fet que Francesc Renart rep l'encàrrec, 
el i 8 I 3 , d'inspeccionar i realitzar els mesuraments $i$ els informes convenients en els convents restablerts després de l'ocupació francesa al bisbat de Girona ${ }^{3}$. Així mateix, trobem també Francesc Renart l'any i 8 I 8 fent una valoració dels edificis enderrocats a Barcelona per part dels francesos ${ }^{4}$.

D'altra banda, una descripció ben gràfica del rector de la parròquia d'Ardèvol (Solsonès) en una carta dirigida al duc de Cardona exemplifica quin era l'estat de moltes esglésies a començaments del segle XIX, on es posa de manifest que la situació de vellúria i ruïna immiment en la qual es trobaven moltes esglésies s'havia accelerat per les vicissituds sofertes durant els períodes bèl-lics:

[...] la intemperie del clima sumamente frío y humedo en invierno, por ser este territorio ocupado en la mayor parte de la dicha estación de niebla muy densa y escarchosa, la poca ventilación de ayres por falta de ventanas y finalmente los estragos y desordenes de las guerras especialmente las de sucesión en el principio del siglo I 8, de la independencia, y de la ultima de revolución constitucional, que todas han descargado con especialidad contra esta parroquia por su proximidad a la plasa y castillo de Cardona, objeto de mucha atención en todas ellas de los partidos que las hacían, han reducido el edificio de esta Iglesia y a sus insinuados retablos no solo a un estado de poca decencia para celebrarse en ellos los santos sacrificios y divinos oficios, pero aun en el de ofrecer la iglesia poca seguridad de que no se desplomen y caigan bovedas y paredes de ella, que se hallan carcomidas, y gastadas de la humedad, y salina en una profundidad que llama mucha atención ${ }^{5}$.

I és que els estralls de la guerra amb França fan que, posteriorment, es duguin a terme o bé es reprenguin nombroses restauracions, des d'esglésies parroquials com ara Cervera o Balaguer, fins a monestirs com ara Montserrat.

També és època de mantenir el recordatori d'ordres i edictes que afectaven l'art i l'arquitectura. Per exemple, l'any i 8 I 4, el rei Ferran VII torna a enviar una circular als bisbes on fa esment de les altres ordres i circulars referents a l'obligatorietat de trametre els projectes de les obres a la Real Academia de San Fernando des de l'any I777, sota el regnat de Carles III. Després d'aquesta data, s'havien succeït noves circulars ( I784, I789, I798, etc.) en temps de Carles IV, «y siendo sin embargo repetidos los recursos que se hacían por su falta de cumplimiento en las ciudades y pueblos inferiores», fins que el 5 de gener de l'any i 80 I es declararen nuls i sense cap valor els títols d'arquitecte $\mathrm{i}$ mestre d'obres que no haguessin estat atorgats per la Real Academia de San Fernando i que «prelados, cabildos, ayuntamientos y gremios hubiesen ex- pedido en contravención de la expresada orden de 28 de febrero de I787». Davant l'evidència, doncs, que, després dels estralls causats per la Guerra del Francès, molts temples que havien estat utilitzats com a caserna militar «u otros usos aún más profanos» serien rehabilitats, així com d'altres edificis públics, es considera necessari trametre novament les reials resolucions «con estrechísimo encargo de su cumplimiento, particularmente en quanto a la elección de arquitectos, en cuyo punto se han notados mayores infracciones».

D’aquesta manera, a part de la prohibició de concedir o reconèixer títols que no haguessin estat concedits per la Real Academia de San Fernando de Madrid o la de Sant Carles de València, també s'exhortava que, segons la mateixa circular de l'any i787: «los arquitectos o maestros mayores de las capitales o cabildos eclesiásticos principales del Reyno sean precisamente académicos de mérito de San Fernando o San Carlos [...] para lo cual, siempre que haya vacante de este empleo, lo avisen a dichas academias». Igualment, es remunta a les ordres del 23 de novembre de $1777 \mathrm{i}$ del 20 de desembre de I798, en les quals s'exhortava a promoure que sempre que es projectés alguna obra pública, fos examinada per la Real Academia de San Fernando, entregant al secretari els dibuixos, els plànols, els alçats i els talls, juntament amb les explicacions pertinents, $i$ tot seria examinat «atenta, breve y gratuïtamente» pels professors d'arquitectura. Un cop rebut el seu dictamen, en el cas que el projecte s'hagués de tornar a fer, quedava a l'arbitri dels interessats acudir a la Real Academia perquè els proporcionés un professor hàbil per dur-lo a terme. També s'especifica que, des de l'ordre de l'onze de gener de i 808, aquestes recomanacions es feien extensives a les obres de pintura o d'escultura realitzades per a llocs públics o temples a expenses de diners públics o altres institucions.

Però, quins eren els instruments de què es disposava a Catalunya a l'hora d'encarar aquesta deriva que es considerava necessària cap a «las reglas del buen arte y arquitectura»? La creació de l'Escola Gratuïta de Dibuix, sota el patronatge de la Junta de Comerç, havia contribuït - juntament amb la tendència il.lustrada representada per determinades autoritats civils i eclesiàstiques i per la influència (més o menys gran) de la Real Academia de San Fernando - a aconseguir que els darrers vint-i-cinc anys del segle XvIII fossin més permeables a un cert classicisme acadèmic. Però hem de pensar que, un cop superada la invasió napoleònica, Barcelona encara no tenia cap acadèmia especialitzada en l'estudi, la teoria i la praxi de l'arquitectura, malgrat que l'any I 797 s'havia produit un intent de crear una escola d'arquitectura; temptativa que fou aprovada per la Real Academia de San Fernando l'any I799, però que, finalment, no reeixí, sobretot per vicissituds econòmiques. La creació de l'Escola
3. BC: Fons Renart. Lligall XXVII, 1 .

4. BC: Fons Renart. Lligall XVIII, 3.

5. ADS: Fons parroquial d'Ardèvol (full solt). 
6. J. Bassegoda Nonell, El templo romano de Barcelona, Barcelona, Reial Acadèmia de Belles Arts de Sant Jordi, 1974 i «Vida y obra del arquitecto Antonio Celles Azcona (17751835)», Academia, 88, 1999, p. 19-30; J.M. MONTANER I MARTORELL, «L'estada a Roma de l'arquitecte català. Antoni Celles, 1803-1815», L'Avenc, 120, 1988 , p. $16-24$ i La modernització de l'utillatge mental de l'arquitectura a Catalunya (1714 1859), Barcelona, 1990.

7. X. BARRAL, «Arquitectura religiosa moderna i contemporània», Art de Catalunya, vol. 5 Barcelona, L'Isard, 1999, p. 169

8. AHCB: Municipal Balaguer Full solt, 1816.

9. J. Florensa, L'escola pia de Balaguer, Barcelona, Publicacions de l'Abadia de Montserrat, 1999. p. 78.
d'Arquitectura de la Llotja de Barcelona - a partir de l'any i 8 I7, que és quan s'iniciaren les classes, en un moment en què s'havia superat mínimament la conjuntura desfavorable de les guerres successives amb Anglaterra i França de finals del segle xviII i principi del XIX - , va subsanar aquest buit existent pel que feia a la possibilitat que els arquitectes o els mestres d'obres poguessin adquirir una sòlida formació a Catalunya sense cap necessitat de desplaçar-se a Madrid.

\section{Antoni Cellers i la seva arquitectura religiosa}

És impossible dissociar l'essència i el significat de l'Escola d'Arquitectura de la Llotja de qui en fou el primer director i alma mater, Antoni Cellers i Azcona (1755-I835). Nascut a Lleida i havent estudiat de jovencell a Saragossa, Antoni era fill del mestre d'obres Pere Cellers, que va realitzar nombroses obres a la Lleida setcentista.

La formació i el "currículum» professional d'Antoni Cellers abans del seu nomenament a la Llotja ha estat estudiat per autors com ara Joan Bassegoda o Josep M. Montaner6. A grans trets, cal assenyalar que havia estat becat tant a Madrid com a Roma, on romangué nou anys, precisament fins que la Junta de Comerç li oferí la possibilitat de ser el primer director de la nova Escola d'Arquitectura de Barcelona. Fou la mateixa Junta de Comerç qui el becà llavors per tal que s'encarregués de conèixer a fons els estudis que s'impartien a Madrid i a Roma, i va dur a terme un elaborat projecte acadèmic que, uns quants anys després, proporcionaria una sòlida formació teòrica i pràctica als arquitectes catalans que s'examinaven encara a Madrid per obtenir el títol. La seva creació, però, no va ser pas exempta de polèmica, ja que molts mestres d'obres sortits dels ensenyaments gremials $\mathrm{i}$ alguns dels quals ja havien desenvolupat una carrera pròpia, es veien obligats a oficialitzar els seus títols, fet que va originar nombroses protestes ${ }^{7}$.

El discurs d'Antoni Cellers amb motiu de la inauguració de la nova escola de la Llotja és demostratiu de quin pretenia ser-ne l'ideari, en la seva defensa de l'arquitectura clàssica com l'arquitectura per excel-lència, que, segons ell, reunia les característiques de senzillesa, monumentalitat, estalvi aparent de materials i equilibri estructural, tot seguint l'estela dels grans tractadistes que bevien de les fonts vitruvianes. L'estudi que es feia de l'arquitectura clàssica, especialment dels temples, es va reflectir clarament en les seves obres, civils o religioses, que reflectien, d'aquesta manera, la simplicitat de formes pròpies d'aquesta arquitectura - en són testimoni l'austeritat en els volums, la puresa en les línies i la senzillíssima decoració de les esglésies projectades pel propi Cellers i pels seus coetanis-, que no les privava, però, de la monumentalitat corresponent.

Però, més enllà del Cellers teòric, acadèmic i docent, l'objecte del nostre treball és parlar dels seus projectes «materials», que foren certament ben pocs i, encara més, centrar-nos en la seva activitat com a projectista d'arquitectura religiosa.

\section{Visures i restauracions}

\section{Primeres incursions ponentines: Lleida $i$ Balaguer}

En primer lloc, trobem Antoni Cellers en terres lleidatanes, concretament a Balaguer, on, l'any I8I6, havia estat cridat per l'Ajuntament "para hacer el devido reconocimiento de la antigua Igla. Parroquial dexando bien trasado el plan que para su recomposición puedan seguir los otros artifices que deban emplearse a la indicada obra; a cuyo fin se le pase luego el ofc ${ }^{\circ}$ correspondiente» ${ }^{8}$.

La seva estada balaguerina seria aprofitada també pels pares escolapis de la ciutat, per tal que examinés l'estat del col-legi i l'església que hi posseïn. Una nota del i 6 de juliol del mateix i 8 I 6 expressa:

El P. Rector y demás Padres de las Escuelas Pias de esta ciudad de Balaguer exponen a V.S.: Que habiendo consultado a Dn. Antonio Cellés Arquitecto académico de inscrito en la de San Fernando y director de la de Barcelona, que se halla en esta ciudad, sobre la solidez y la seguridad de las paredes y tejado de $n^{\circ}$ colegio, que nos parecía amenazaba en desplomarse en gran parte y sepultara en sus ruínas unos doscientos cinquenta niños escolares con sus maestros; dicho Sr. Arquitecto Dn. Antonio Cellés después de un largo y detenido reconocimiento ha respondido: Que él miraba como un milagro, que no hubiese ya mucho hace venido abajo gran parte del tejado y paredes del Colegio; y que no podía por instante responder de su seguridad: añadiendo que por el pronto se podía remediar con algunos puntales de muy poco coste; bien que sin pérdida de tiempo era menester hacer otras obras, con lo qual nada habrían en adelante que temer.

Es decideix, doncs, tancar l'escola, atès «lo poco Colegio que nos dejó la rapacidad y fuego del bárbaro francés»?.

\section{Olot i la pedra volcànica}

L'any i 8I9, el trobem reconeixent un altre gran temple, en aquest cas no pas gòtic, com la parroquial de Balaguer, sinó de mitjan segle xviıI, com és l'església de Sant Esteve d'Olot, amb la finalitat 
d'emetre un informe que determinés l'estat i l'origen dels problemes estructurals de l'obra, alhora que també s'havia d'erigir com a màxima veu autoritzada per dilucidar una solució efectiva a la inestabilitat de l'església, que tot plegat s'havia construit a mitjan segle anterior ${ }^{10}$.

De l'examen que va fer sobre els materials que componien l'edifici - sobretot la pedra volcànica, tan pròpia de la zona-, Cellers escriurà un assaig sobre la pedra volcànica aplicada a la construcció, aprofitant la seva estada a la ciutat i l'oportunitat de conèixer sobre el terreny les característiques $i$ les possibilitats d'aquest material, la greda, que ell compara amb la pedra tova utilitzada pels romans en exemples d'arquitectura tan monumental com les termes de Caracalla o de Dioclecià, atès que es tracta d'una pedra lleugera per suportar l'audàcia de les voltes ${ }^{11}$.

Al voltant d'aquesta «descoberta», a la Real Academia de San Fernando es documenten diverses cartes d'Antoni Cellers i de membres de l'Acadèmia sobre aquest tema, com ara la carta dirigida a Juan Pasqual Colomer durant el mes de maig de I 82 I sobre l'enviament dels materials de pedra volcànica per tal que siguin analitzats:

Muy Sr. Mío de mi mayor aprecio envio a Vm. el cajoncito con la puzolana y piedras volcanizadas, bien entendido que sacando un buen puñado de cada especie y una piedra de diferente calidad para el Sr. Dn. Manuel Martín Rodríguez mi venerado maestro, lo demás podrá dividirlo en dos partes, una para nuestra academia y otra para la sociedad matritense, entregando a cada cuerpo I 3 exemplares de los míos y uno de otro sujeto a quien no conozco pero que ha escrito sobre Olot.

El cajón dicho va sellado por el ayuntamiento de dicha villa y dentro de el van ejemplares que envié al referido pays y dentro han metido además una certificación diversa de la que remito dichas materias y los aprovó, además la academia de artes y ciencias naturales de esta hizo otro examen. El Sr. Dn. Manuel Martín Rodríguez podrá si gusta hacerlas analizar las tales materias por un químico amigo suyo, catedrático de matemáticas de los pages de S.M. y así la dirección de canales y caminos, nuestra academia madre y la sociedad económica matritense podrán satisfacerse completamente. Deseo no obstante que vm. se sirva en mi nombre oficiar a dichos cuerpos a fin que conste la entrega de dichos materiales y su resultado analítico, esperando que la dirección de canales compuesta de los Sres. Rodríguez, Garramendi y otros hará otro certificado sobre el recibo y análisis.

Se desea que vaya todo con dicha formalidad, porqué los de la villa al pedir a las cortes la prohibición de puzolanas estrangeras se apo- yarán al análisis e informes de dichos cuerpos y a los de acá. Vuestra merced verá si es más conveniente abrir delante de la academia o de la sociedad dicho cajón sellado a fin que conste la autenticidad.

Por lo demás vm. se servirá avisarme de su recibo y resultados, quedando ya satisfechos los portes. Perdone por Dios tanta molestia. La diligencia lleva el cajón pero tardará aun algunos días no se quantos; espero estará vm. alerta para recogerlo.

Creo que vm. y los Sres. Consiliarios y profesores de esta academia habrán visto mis artículos de bellas artes dirigidos a la junta funeraria (llamada patriótica) del General Lacy, pero ella no responde y yo insistiré en mis trece por honor a las artes y a sus hijos ${ }^{12}$.

Precisament el destinatari de la carta anterior, l'acadèmic Juan Pasqual Colomer, expressa el següent el 5 de juliol del mateix I 82 I:

Conforme a los deseos y petición del Sr. Celles se dividieron por mitad dichos minerales y ejemplares impresos, quedando la una en la sociedad y la otra para nuestra Academia, excepto un poco de puzolana que se ha sacado para entregar en la inspección general de puentes y caminos. Esto supuesto acompaó a V.S. los adjuntos papeles de aquel profesor para nuestra Academia, trece ejemplares de sus observaciones impresas, y uno de las de otro barcelonés sobre los volcanes apagados de Olot; diez piedras vulcanizadas y una porción de puzolana negra y roja. Sírvase v.s. hacerlo todo presente a la Academia para los fines que expresa y puedan convenir al intersado ${ }^{13}$.

En una junta ordinària de l'Acadèmia, el I4 d'abril de I 822 tornem a trobar referències sobre el tema per boca, aquest cop, de Julián de Barcenilla:

En diferentes juntas celebradas por la comisión de arquitectura de la Academia de San Fernando y señaladamente en la última del i i de este mes, se han examinado la puzolana y piedras volcanizadas de la villa de Olot en el Principado de Cataluña las que analizadas detenidamente $\mathrm{y}$ hechos varios experimentos al intento, resultan los mismos efectos que anuncia en sus observaciones el arquitecto académico de mérito d. Antonio Celles, por lo que la Comisión juzga sería de desear que se generalizase el uso de la puzolana mesclada con cal en todas las obras de agua y las piedras porosas vulcanizadas en la construcción de bóvedas, pues por su extremada ligereza y configuración facilitarían las de un grandor extraordinario; así mismo la comisión es de parecer se diga al insinuado Celles que su
10. L'informe d'Antoni Cellers ha estat reproduit en totes les publicacions que parlen exhaus tivament de l'església de Sant Esteve, des de J. PAgÈs I Pons, L'església de Sant Esteve d'Olot, Olot, Alzamora, 1986, fins a DANÉs I ToRras (volum XIII)

11. A. Celles, Discurso que en la abertura de la Escuela Gratuïta de arquitectura establecida en la ciutat de Barcelona por la Real Junta de Comercio del Principado de Cataluña dixo el dia 11 de setiembre de 1817 Don Antonio Celles y Azcona Director de aquella escuela, $y$ académico de mérito de la Real Academia de San Fernando, Barcelona, Impremta de Agustin Roca, 1817.

12. RABASF: 3-123 Secretario general. Libro de actas de sesiones particulares.

13. RABASF: 3-123 Secretario general. Libro de actas de sesiones particulares. 
14. RABASF: 3-123 Secretario general. Libro de actas de sesiones particulares.

15. RABASF: 3-123 Secretario general. Libro de actas de sesiones particulares.

16. RABASF: Legajos (2-33-5). laboriosidad y exquisito cuydado en investigar y generalizar las propiedades y uso de las piedras de la citada villa de Olot, han merecido un particular aprecio de esta Academia ${ }^{14}$.

Un mes després, en la junta ordinària del I 2 de maig del mateix I 822, es dóna compte d'una carta del mateix Antoni Cellers en aquests termes:

Con suma satisfacción he recibido el oficio de V.S. que con fecha del i 8 del mes próximo pasado se ha dignado mandarme comunicar, noticiándome en el que el análisis hecho con las puzolanas de la villa de Olot corresponde a las observaciones que yo publiqué sobre el particular en el año i 820.

Si para mi me es sumamente grato el haber sido premiado por la Academia de Ciencias Naturales y Artes de esta Capital y por la Sociedad Económica Matritense con el título de socio emérito de ambas corporaciones por el descubrimiento y análisis que hize de las materias volcánicas de aquella villa, me es aún más lisonjero el que un cuerpo de bellas artes haya acabado de confirmar los mismos resultados.

Agradeciendo sobre manera a V. A. el estímulo con que anima a mis tareas y débiles talentos, me ofrezco corresponder en quanto esté de mi parte al alto aprecio con el V.A. se digna honrar al más ínfimo de sus individuos ${ }^{15}$.

La correspondència posa de manifest que Cellers havia traslladat el seu assaig a dues institucions més de caràcter científic: l'Academia de Ciencias Naturales i la Sociedad Económica Matritense, enviament $i$ estudis que foren compensats amb el seu nomenament com a soci emèrit de les esmentades entitats.

\section{Retorn ponentí: l'església irrealitzada del Vilosell i el canal d'Urgell}

La població del Vilosell (les Garrigues) barallava la possibilitat de construir una església nova almenys des de I8I6, quan l'indret on s'havia de construir el nou edifici fou designat pels «arquitectes» fra Joaquim Tarragó, religiós profès del monestir de Poblet, i Josep Daura, que figura com a «habitante en el dicho monasterio».

L'any I8I9, Antoni Cellers rep l'encàrrec de traçar els nous plànols per la quantitat de 448.670 rals i l's de maig els envia a l'Acadèmia amb les explicacions següents:

[...] por otra parte como mis diseños tienen diversas notas las quales advierten que unos maestros albañiles habiendo escogido el sitio para la

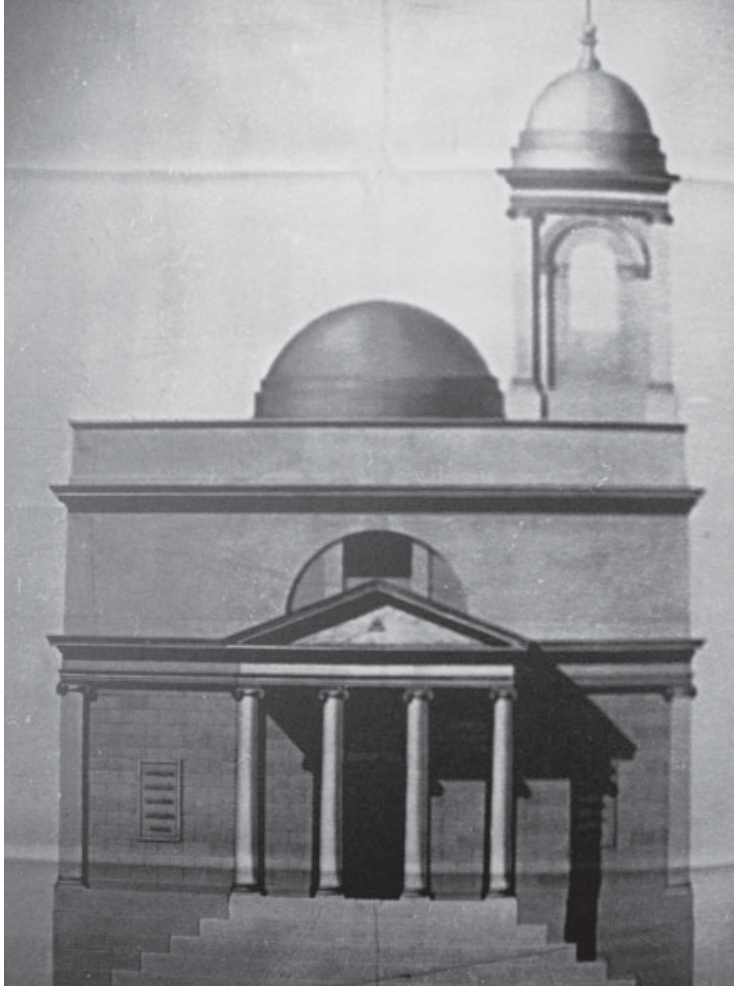

Figura 1.

Primer projecte per a l'església del Vilosell (Garrigues). AHN: Consejos. Legajos 37.450. CADIÑanOS, I: «Documentos para la Historia del Arte en la Corona de Aragón. II. Principado de Cataluña» a Boletín del Museo e Instituto Carrión Aznar, núm. XCVI. Zaragoza: Ibercaja. Obra Social, 2005.

formación de la iglesia y que yo había sido obligado a ceñirme a el por no mover nuevas disputas y pleytos entre los vecinos de dicho pueblo, resultando de ello graves inconvenientes a mi proyecto, quales son el ser situada la iglesia en unas calles inclinadas, angostas y tortuosas y en un sitio estrecho, lo que me produjo necesariamente un basamento sumamente alto, un pórtico muy angustiado, una escalinata que debe subirse por las partes laterales del pórtico, por falta de plaza al frente de la iglesia, suplicaba finalmente a continuación de dichas notas que S.M. se dignase mandar escoger otro sitio para la formación del proyecto, a fin que reuniera todas las ventajas sin incurrir en los indicados defectos.

Bajo estos datos desean los del pueblo de El Velusell y yo igualmente, saber el dictamen o censura dada por la academia sobre dicho proyecto, a fin de hacer otro que reúna lo dispuesto para la misma con respecto a su dictamen o censura ${ }^{16}$.

La resposta de l'Acadèmia no es fa esperar, es produeix amb data de $\mathrm{I} 2$ de maig i se'n desprèn que Antoni Cellers hauria de refer els plànols:

Al mismo tiempo que aprobó la Real Academia de San Fernando en su junta ordinaria de i 8 de octubre último los cuatro planos remitidos por 


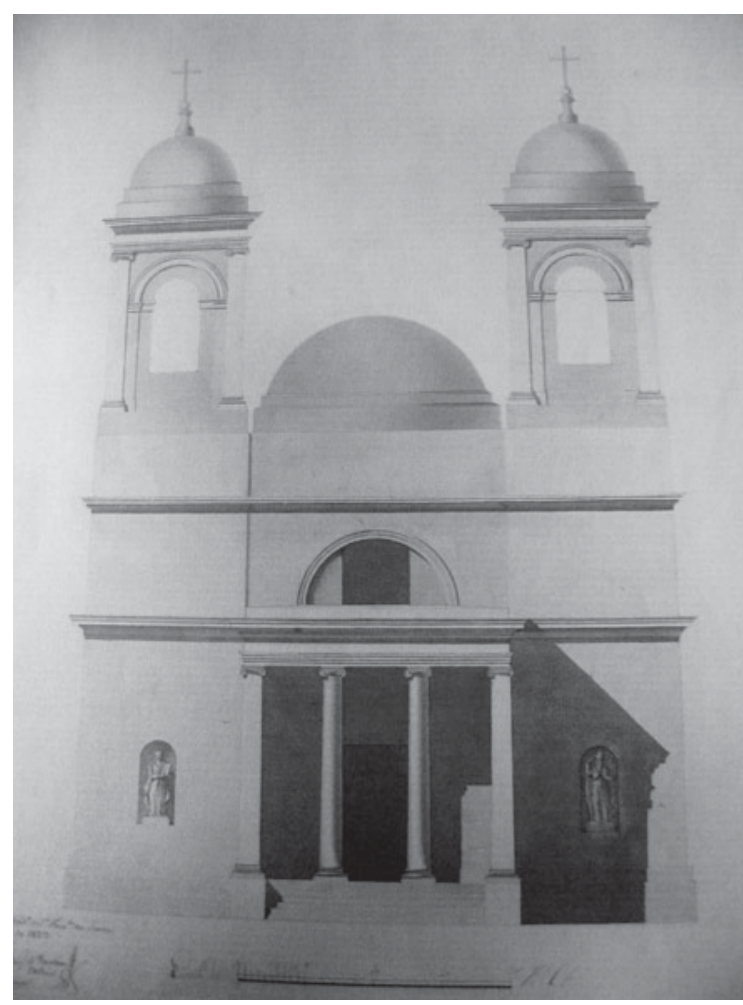

Figura 2.

Segon projecte per a l'església del Vilosell (Garrigues). AHAT: Fons parroquial del Vilosell.

el consejo Real y formados por Vuestra Señoría para convertir en cárceles la antigua iglesia de San Martín de la ciudad de Lérida, teniendo presente el pliego de reflexiones y avance de todas las obras, no pudo dispensar igual aprobación al proyecto de nueva iglesia parroquial para el lugar de Velusell, que también se remitió de orden del Consejo a examen de la Academia, a la cual pareció entre otras cosas que el perímetro de la iglesia no se halla arreglado por quedar solo cinco pies de ancho en el paso de una de las calles de la derecha, debiendo por lo menos de once, faltando también informe facultativo y cálculo de su costo, por lo que era necesario que V.S. formase nuevos dibujos y los remita antes en borrador en lineas según está mandado por la Academia ${ }^{17}$.

Podem suposar que els primers plànols enviats a l'Acadèmia devien ser els que ens presenten l'església amb una sola nau i un pòrtic tetràstil d'ordre jònic i rematat per un frontó triangular, per damunt del qual n'emergeix una finestra termal. La testera de la façana és plana, amb una cornisa senzilla i, en un extrem, se sobreposa la torre campanar culminada amb una cupuleta, petita rèplica de la mitja taronja que representa la traducció externa de la cúpula del presbiteri. Hi ha set graons que eleven el pòrtic respecte al pla del carrer. Aquest projete no es durà a terme (ni que s'haguessin fet les modi- ficacions pertinents), bàsicament per un problema de finançament i de manca d'acord amb els delmadors. És per això que llavors trobem un parèntesi documental de catorze anys, fins que, l'any I833, es torna a reprendre el projecte de materialitzar una nova església. Així el descrivia Antoni Cellers en una carta del i 6 del mes de juliol de I 833:

A fin de secundar el artista los deseos del expresado cuerpo se ha ceñido a hacer un proyecto sencillo y sin adornos, procurando no obstante reunir en él la conveniencia, la solidez, la belleza y la economía, cuyo pensamiento somete gustoso a la censura y aprobación de la Real Academia. El cálculo aproximado de la obra nueva de dicha iglesia asciende a 420.008 reales de vellón la albañilería y la cantería, a 22622 reales la carpintería, a 4920 reales la cerrajería, y a I080 la vidriería; y el total de los diversos oficios a 448670 reales de vellón, y el de la compra del terreno en donde deberá construirse importarà 47.000 reales, cuyo total llegarà a 495.670 reales de vellón, siendo de advertir que piedra tanto para la sillería como para la mampostería se halla casi al pie de la obra.

Dicha iglesia será capaz de 600 a 700 almas a la misma se le ha dado la disposición interior que presenta, con el fin de poder hacer dentro de ella procesiones quando convenga.

Podrá tener la misma io altares, comprendidos el mayor y el del Santísimo Sacramento, quedando un capaz presbiterio, sacristía, trastero y un buen coro alto ${ }^{18}$.

Cellers havia traçat, doncs, uns plànols nous que, si bé seguien les línies generals dels anteriors, hi presentaven també diferències remarcables, com ara la introducció, en aquest cas, de torres campanar a banda i banda de la façana, si bé tenien les mateixes característiques que el campanar del projecte anterior. En aquest es manté el pòrtic tetràstil, però sense frontó. Al seu lloc, hi emergeix directament la finestra termal que faria les funcions de rosassa, separada del pòrtic per una cornisa que actua com a divisòria horitzontal de la façana. A banda i ban$\mathrm{da}$ del pòrtic - aixecat sobre una escalinata menys prominent que la del projecte anterior-, hi ha una fornícula amb imatges. Segons Montaner:

Com es veu a primer cop d'ull, és una església resolta amb la més pura ortodòxia neoclàssica $i$ amb la voluntat ben evident de crear partint de les formes més pures i de la manca d'ornamentació més radical. Els elements característics de les esglésies de final del segle XVIII i principi del XIX - campanars, atris, finestres, cúpules, fornícules, cornises, etc. - són resolts amb l'abstracció més radical. En canvi, amb la planta, rectangular i ordenada, no seguia el tipus de planta lliure o
17. RABASF: Legajos (2-33-5).

18. RABASF: Legajos (2-33-5). 


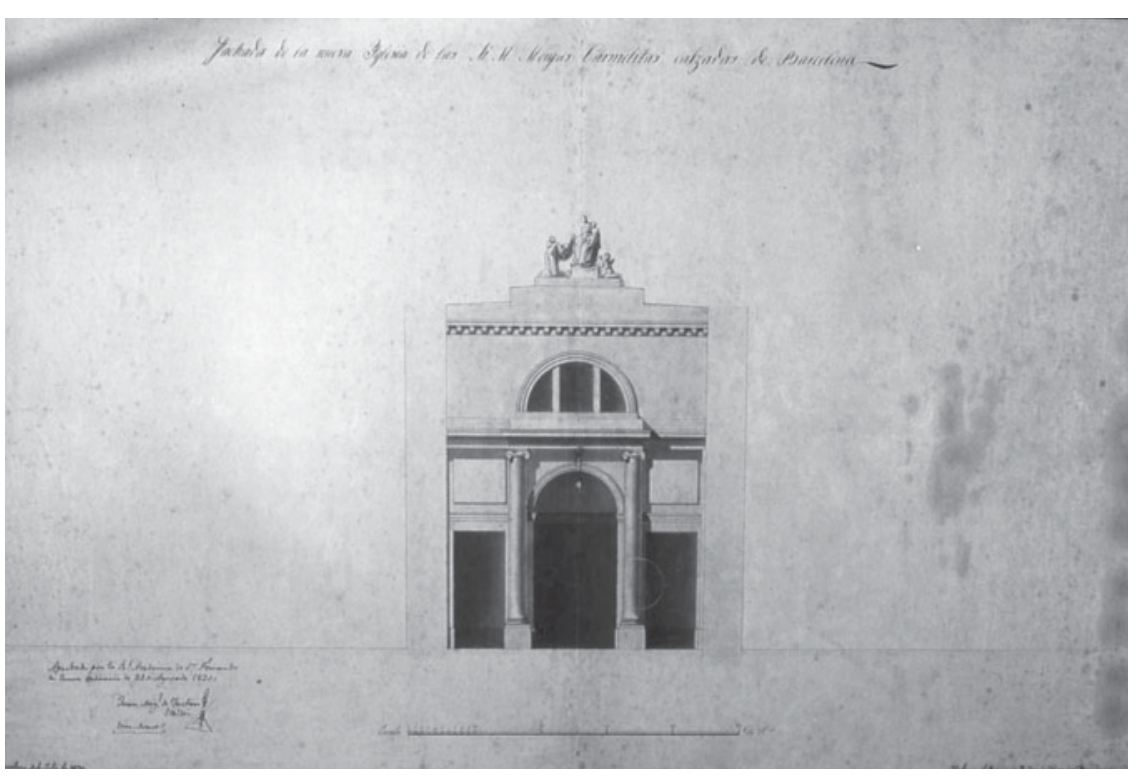

Figura 3.

Projecte d'Antoni Cellés per al convent del Carme del carrer Hospital (Barcelona). Arxiu de la Reial Acadèmia Catalana de Belles Arts de Sant Jordi.

19. J.M. Montaner i MartoRELL, op. cit., p. 578

20. RABASF: Legajos (2-31-5)

21. De la bibliografia relacionada amb el canal d'Urgell, n'hem sel-leccionat els títols següents de referència: J. MATEu GiRALT, La pagesia urgellenca abans del Canal, Barcelona, Fundació Salvador Vives i Casajuana, 1982; J. REÑÉ, Història del Canal d'Urgell (1346-1862), Fondarella, Edicions Palestra, 1990; J. VILA, Els Canals d'Urgell $i$ la seva història. Lleida, Diputació, 1992.

22. RABASF: Legajo (2-32/2).

23. Plànol localitzat als Quarterons Garriga de 1859 i referenciats per Bassegoda (1974) i Montaner $(1990,576)$.

24. APEPC: A-IV-1. Llibre que conté els Datos relativos a la construcción de la iglesia.

Foli 1: "Libro en que se notará todo lo ocurrido para la nueva iglesia del Rl. Colegio de Escuelas Pías de Sabadell que por autografo decreto signado de su Rl. mano se dignó costear por los fondos de su Rl. Patrimonio el 22 Enero de 1829 el bondadoso corazón de Fernando VII que Dios que añadiendo despues visto el cálculo del arquitecto Dr. Antonio Celles de veinte y cinco mil duros; todos los suplementos necesarios caso de no bastar aquellos para la obra calculada, como si consta en el archivo.

Se dio principio a la obra el 3 de enero de 1831. Con solemnísima procesión se trasladó de la antigua iglesia a la nueva el Santíssimo sacramento en el día 9 de setiembre de 1832». planta saló, d'espai homogeni - típica estructura tipològica de l'església neoclàssica-, sinó que encara hi dominaven la jerarquia i la matisació espacial barroca ${ }^{19}$.

En principi, i com havia succeit en la primera temptativa, més d'una dècada abans, també haurien estat els problemes derivats del finançament els que haurien impedit la materialització del projecte. A partir d'aquest mateix any 1833 , però, Antoni Cellers se submergia en una empresa encara de més envergadura, duta a terme també en terres ponentines - i que si tampoc fou executada de forma immediata, sí que va constituir la fase per a la seva materialització definitiva, unes quantes dècades més tard-, com seria el canal d'Urgell.

Així doncs, la junta de l'Academia de San Fernando aprovava, el 2 I de juliol de i 833, el projecte de Cellers per a l'execució del canal d'Urgell «con la respectiva relación facultativa y cálculo que dedujo de la más atenta inspección del terreno, exactas nivelaciones de 53 leguas del mismo y demás operaciones que ha tenido por oportunas al mejor desempeño de su cometido» ${ }^{20}$. En la sol-licitud que fa, Antoni Cellers hi especifica que:

[...] hallándose encargado de los proyectos del canal de riego de Urgel y de la iglesia parroquial del pueblo del Vilusell (ambos de Cataluña) ha formado 46 planos para la ejecución del referido canal, con su respectiva relación y cálculo, deducido todo de la atenta inspección del terreno, nivelaciones exactas de 53 leguas del mismo y también ha hecho 5 dibujos para el proyecto de la indicada iglesia parroquial, que acompaña igualmente con su relación y cálculo.
Canal d'Urgell i església del Vilosell, doncs, són projectes que coincideixen en el temps i gairebé en l'espai, si bé la fortuna de l'un i de l'altre fou ben diversa ${ }^{21}$.

\section{Intervencions monàstiques $\mathrm{i}$ conventuals: l'abadia de Montserrat i el Carme Descalç de Barcelona}

De la intervenció d'Antoni Cellers al monestir de Montserrat en sabem que fou propiciada per les obres necessàries a causa de la destrucció parcial que patí el monestir, ja que va ser incendiat durant la invasió napoleònica. L'any I 829, l'abat escrivia a l'Academia de San Fernando reclamant una solució a la mala praxi de l'ebenista Picanyol, que havia començat a restaurar el presbiteri dos anys abans, però amb resultats poc reeixits. És per això que, juntament amb Andrés Bazán, Antoni Cellers fou cridat a continuar les obres ${ }^{22}$.

Però si bé la intervenció de Cellers a Montserrat fou del tot respectuosa amb la idiosincràsia de l'edifici, en el cas del convent de les carmelites descalces del carrer de l'Hospital, a Barcelona, es tractava d'una obra de nova planta, per la qual cosa podia desplegar el seu geni com a projectista. I seria en aquesta obra i sobretot en la planta de l'església, malauradament desapareguda, que s'hi palesaria la influència barroca al més pur estil de la Roma siscentista, segons el plànol d'aquest conjunt, construït entre I 830 i i 833 i que fou enderrocat l'any I $894^{23}$. Accessible des d'un pati rectangular, l'articulació de l'església en una planta central ovalada amb capelles també absidials a tot volt, fa pensar indiscutiblement en el model berninià de Sant'Andrea al Quirinale, si bé la presència d'un espai el-líptic a l'entrada recorda la gradació d'espais en diverses el-lipsis d'esglésies com ara San Marcos de Madrid, de Ventura Rodríguez. D’altra banda, però, la façana sí que reprén la suggestió palladiana amb el pòrtic tripartit, la finestra termal al lloc de la rosassa i una cornisa superior, amb un remat lleugerament esglaonat, que també utilitzaria a l'esglèsia escolàpia de Sabadell.

\section{L'església dels escolapis de Sabadell: un projecte materialitzat}

Les gestions i el procés constructiu d'aquesta església sabadellenca es recullen en un manual intitulat Datos relativos a la construcción de la iglesia, dedicat íntegrament a aquesta qüestió i escrit pel llavors pare provincial de l'Escola Pia fra Tomàs Miret de la Visitació ${ }^{24}$. La fundació d'una escola pia a Sabadell es remunta a l'any i 8 is, quan l'Ajuntament de 
Sabadell inicià les gestions amb el pare provincial anterior, Pelegrí Martí, amb qui va signar un conveni segons el qual l'Ajuntament es comprometia a pagar la quantitat de 600 lliures anuals, recaptades dels fons d'arbitris, així com a donar una casa proporcionada per «un bienhechor adicto», que, en aquest cas, seria Don Antoni Cortés de Andrade, marquès de Ciutadilla, descendent dels Claresquí i dels Meca, que el 26 de febrer de I 8 I 6 signa l'escriptura de cessió de la casa Meca i del seu hort, posant com a condició que el patró del col·legi i l'església que es construís fos sant Agustí i que hi figuressin dues pintures on es representés el propi marquès fent donació de la casa Meca a l'Escola Pia. D'altra banda, els escolapis es comprometien a mantenir constantment quatre mestres al collegi: un per ensenyar a llegir, un altre a escriure i comptar, un altre per ensenyar llatí i un altre per impartir retòrica i humanitats, al mateix temps que també es comprometien a predicar en quatre festes convingudes. Del 5 de març de I8I 8 és quan data la carta de fundació, atorgada pel rei Ferran VII. Finalment, la comunitat escolàpia va quedar constituida a principis de setembre ${ }^{25}$.

Un cop constituït el col-legi, la ubicació de la nova església té el seu origen en diverses donacions de terrenys dutes a terme a partir de l'any i 8I9 per particulars ${ }^{26}$ i per l'Ajuntament de Sabadell, terrenys que, l'any I $83 \mathrm{I}$, van ser canviats per una porció de terreny - més adient per a les necessitats de l'escola - cedida pels administradors de l'hospital, a l'altra banda del carrer del Pedregar. Aquests posaven, però, com a condició que, a més de donar servei al col·legi, l'església també havia de ser utilitzada pels malalts, pels convalescents i pels passavolants, ja que l'indret era molt proper al camí ral de Barcelona a Manresa i se situava ben bé vora l'anomenat Portal de Barcelona.

Les gestions per construir una nova església van començar al mes de gener de i 829, quan el pare provincial Tomàs Miret de la Visitació adreçà un memorial al rei, en el qual li comunicava la intenció de la congregació de construir una nova església. Li demanava autorització per fer-ho i també collaboració en aquests termes:

El is de marzo de I 8 I 8 mereció vuestra Rl. Cedula para el nuevo establecimiento de Escuelas Pías de esta villa de Sabadell. Reboza de contento al ver concurrentes a ella cerca de quinientos niños; pero penetra su corazón en el dolor por no poder dárseles la competente espiritual instrucción a los más de ellos por la suma estrechez de la iglesia de solas I 4 varas, tres palmos de largo y tres varas de ancho; que más parece oratorio o capilla que iglesia. No se pueden practicar en ella los exercicios espirituales ni menos desempeñar los maestros las augustas funciones de su instituto $[\ldots]^{27}$.
El pare Miret ja havia rebut els reis, Ferran VII $i$ M. Amàlia, quan aquests s'havien allotjat al col-legi escolapi durant els dies 9 i i o d'abril de i 828, durant el seu viatge de Barcelona a Montserrat, per la qual cosa gosava demanar directament el favor del rei en aquest assumpte.

Aquesta súplica va tenir una resposta efectiva, ja que, tan sols quinze dies més tard, el rei va emetre una reial ordre que li fou notificada al batlle general del Reial Patrimoni de Catalunya, segons la qual:

[...] que por los fondos de ese Real Patrimonio, a medida que los mismos lo permitan, y sin desatender las obras del Azud de Flix para que están destinados con anticipación; se costee la obra que la referida comunidad va a emprender para ampliar la capacidad de su iglesia en el sitio de cinquenta y nueve varas que el Recurrente expresa en su solicitud habérsele concedido a dicho fín.

El pas següent del pare Tomàs Miret fou dirigir-se a Antoni Cellers, per tal de demanar-li que es fes càrrec de la formació dels plànols i de la direcció de l'obra, així com d'enviar el projecte a la Real Academia de Bellas Artes de San Fernando. També li va recomanar que, quan es preveiés qualsevol despesa extraordinària, es posés en contacte amb el batlle general del Real Patrimonio, atès que totes les despeses quedarien incloses en el preu total de l'església. Però finalment va ser el propi Tomàs Miret qui va remetre el projecte el 2 I de juliol perquè fos sotmès al dictamen de l'Acadèmia. El llibre de notes del pare Miret conté la reproducció del text que acompanyava els plànols presentats a la Real Academia i que constituia l'explicació del projecte (vegeu el document número 3 de l'apèndix).

El i 2 de maig de i 830, el provincial de l'Escola Pia, fra Tomàs Miret de la Visitació, envià a Madrid els dibuixos en net que Antoni Cellers realitzà per a la nova església «a fin que desde luego pueda pasarse a la formación de todas las expresadas obras ${ }^{28}$, que havia de ser sufragada pel rei amb els fons del Reial Patrimoni. El projecte fou aprovat en la junta del I 3 de juny del mateix any i els plànols van ser retornats a Sabadell perquè Cellers els passés a net «sin más variación que la que pueda incurrir en su mejora». El I4 d'agost, es van col-locar, a les estances rectorals, els quatre plànols i dibuixos amb la signatura i el vistiplau del secretari de la Real Academia de San Fernando, emmarcats i protegits amb un vidre.

A finals d'agost, el batlle general del Real Patrimonio, Manuel Ibarra, escriu al pare Miret explicant-li que encara ha de consultar a instàncies superiors la quantitat disponible a la tresoreria patrimonial que es troba al seu càrrec, de manera que sol-licita la informació més precisa possible sobre el cost que ha de tenir l'obra «en corta diferencia [...] para con esta arreglar mis operaciones y calcular en
25. El Diari de Barcelona fa una referència, el dia 2 de setembre, a l'esmentada fundació: «La villa de Sabadell agradecida al singular favor con que la ha favorecido su augusto y religioso monarca D. Fernando VII, con la fundación de un colegio de PP. de las Escuelas Pías para la enseñanza pública de dicha villa y su comarca, ha resuelto en obsequio a tan singular favor y abertura de sus aulas, dar al público dos días de fiestas que serán en los días 6 y 7 de este mes».

26. APEPC: Caixa 07/41, núm 2 , plica primera.

27. APEPC: A-IV-1. Libro que contiene los Datos relativos a la construcción de la iglesia.

28. APEPC: : A-IV-1. Libro que contiene los «Datos relativos a la construcción de la iglesia», fol. 19. 
la forma y plazos en que podría hacer la entrega de caudales», i afegeix a la seva sol-licitud al provincial dels Escolapis que

[...] remita el proyecto, diseños y cálculo de la expresada obra, para que S.M. vea que es lo que se quiere hacer y determinar acerca de esta, y de la suma a que asciende su importe lo que más fuere de su soberano agrado conforme a su Real Decreto de 22 de Enero de i 829.

La resolució es farà esperar dos mesos i mig. Segons aquesta, el rei concedia la quantitat de 500.222 maravedís de velló, procedents dels fons de la Batllia General del Reial Patrimoni de Catalunya, a més dels suplements necessaris en cas que no n'hi hagués hagut prou amb la quantitat acordada. L'import s'entregaria en tres parts, la primera de I66.046 maravedís i l'encarregat d'acudir a la Batllia General per cobrar-la seria el pare Freixa de Sant Camil de Selis. Un cop cobrada aquesta primera part, es va començar l'obra el 3 de gener de I 83 I, amb tres carros i catorze treballadors.

La colllocació de la primera pedra no es va dur a terme fins al 7 de març de I83 I. Es va tractar d'un acte solemne i molt concorregut, fins al punt que es van haver de prendre algunes mesures de seguretat, atesa la impossibilitat que el recinte acollís tot el públic assistent. Segons paraules del pare Miret:

Temiendo las desgracias involuntarias que podría causar una concurrencia excesiva: fue preciso limitar la entrada, mandando poner centinelas de los mossos de escuadra con orden de no dar paso, sino a los arriba nombrados. A pesar de ello, el público animado por la circunstancia le congregaba, se puso para cuanto pudo ver de la función y tranquilo premiaba con su contento y sus elogios los piadosos efectos del soberano por una obra tan interesante a la Religión y al Estado. Las campanas de los templos con la música bien concertada aumentaban el gozo de los concurrentes. Concluída la carrera de la procesión en la que no faltaron pocas lágrimas de la mayor ternura y llegada a su destino, collocada en la vigilia la cruz, pendiente de ella esta cuartilla: «Esta es la cruz principal, / que como airosa bandera / se levanta la primera / el esta iglesia Real ${ }^{29}$.

Després dels actes religiosos, i un cop col-locada la primera pedra, la festa va concloure amb l'espectacle següent:

[...] fuegos artificiales de cohetes, correos voladores, hachas y ruedas. De los cohetes unos subían a línea recta a tanta elevación que casi se perdían de vista, de otros no se notaba su curso y solo se oía su estallido. Estos fuegos se empeñaron en dar noticia de los regocijos públicos de esta villa y comarca con plausible motivo a las estrellas. No menor fue el gusto que dieron a los espectadores las hachas y ruedas. El fuego aunque duró una hora pareció al numeroso concurso que se había concluído con un minuto por la singular complacencia con que todos lo miraban.

El mateix text del pare Miret explica com es va començar a construir l'església, alhora que n'ofereix una exhaustiva descripció:

Colocada la primera piedra, se pasó a macizar los profundos y gruesos cimientos de la iglesia y obra con la que la casa colegio se comunica con ella. La dicha iglesia es de forma ovalada cuya longitud con el presbiterio y entrada que está debajo del coro es de I 54 palmos siendo 64 su latitud. En dicho óvalo hay cuatro capillas menores y dos mayores, además del altar mayor presbiterial a la derecha e izquierda de este se hallan la sacristía y oratorio para prepararse y dar gracias los sacerdotes: También a la derecha e izquierda de la iglesia hay una capilla para confesar a los niños y la escalera que comunica con el mencionado colegio por un ancho paso, debajo del cual hay un grande arco que forma la puerta de entrada a la villa. Encima de la sacristía y oratorio se han hecho tribunas y sobre la entrada y capilla de la penitencia está el coro y un trascoro. Para aprovechar la irregularidad del terreno en el piso bajo se formaron 4 piezas en donde poder reunir los niños a fin de enseñarles los ejercicios cristianos.

La indicada iglesia capaz de 500 niños tiene sus basamentos, basas y porción de las i 8 pilastras de sillería bien labrada como así mismo las dos columnas jónicas aisladas que sostienen el coro, siendo lo demás de las paredes de buena mampostería y de obra cocida lo restante de las pilastras, cornisas, bóvedas, teniendo estas últimas o artesones o fajas con recuadros. También son de ladrillo las columnas, pilastras y entablamientos de los altares enlucidos con buen yeso y en su fondo lucen magníficos cuadros al óleo. La gran cúpula semiesférica que cubre la parte principal de la iglesia tiene un grueso competente y estan sus ladrillos de rosea situados con mezcla capaz de resistir las lluvias y a los hielos, y en el centro de dicha gran bóveda hay una ventana horizontal cubierta con cristales, con la cual queda iluminada la iglesia con luz casi igual en todo el curso del día.

La fachada del templo se eleva sobre un podio o basamento de sillería sobre el cual hay 4 colosales columnas de sillería con sus basas y capiteles jónicos siendo de ladrillo su entablamiento: en el centro de la fachada se halla una gran puerta con sus ricas jambas, cartelas y cornisa de can- 
tería, y en los intercolumnios laterales se hallan unos nichos de i 8 palmos de altura y sobre estas dos grandes lápidas con inscripciones de letras que dicen en la de la mano izquierda: Erexit tempum Fernandus Septimus istud / patribus et pueris, Rex pietate micans. En la derecha se lee: «D.O.M. Operi aspiciat / Ferdinandus Septimus Hispaniarum / Rex / P.P.P.C. A fundamentis erexit / Nomis Martii/ Anni MDCCCXXXI / Antonius Celles Architectus / Delineamenta duxit».

Descansa encima de dicho columnato un ático coronado con una cornisa con modillones, y al plomo de las lápidas existen dos modillones de escultura que representan el de la derecha cuando presidiendo S. Calasanz la oración continua, se le apareció delante de los mismos niños la Virgen Santísima con su precioso hijo en los brazos, quien a ruegos de la Madre les echó la bendición, y en ellos a todas las escuelas fundadas y que se habían de fundar en adelante; y el de la izquierda al católica Rey Fernando Séptimo que por medio de un genio entrega una iglesia que reciben los PP. de la Escuela Pia, y a más un grupo de niños elevados sus ojos y manos al cielo implorando todos bendiciones para tan pío como benéfico monarca. Finalmente descuella sobre lo más alto de la fachada la gran estatua del S. Josef de Calasanz Patriarca y Fundador de las Escuelas Pías rodeado de niños, mitra y capelo a sus pies, la cual tiene I 4 palmos de altura.

La total elevación del templo es de i I7 palmos y termina piramidalmente con la gran cúpula que en su exterior tiene 96 palmos de longitud y 80 de latitud, agrupando muy bien con un elegante campanario. Precioso monumento que hará inmortal la memoria del religioso rey Fernando Séptimo. Por tanta beneficencia no solo debe la Real Magestad de Fernando Séptimo lograr ara y estátua en el nuevo santuario, sino templo en cada uno de los corazones de los PP. de las Escuelas Pías como igualmente de los individuos todos de Sabadell y su comarca ${ }^{30}$.

El dia 8 de setembre, es va beneir el nou temple, i el trasllat del Santíssim a la nova església estava previst per al matí del dia 9. Aquest es va dur a terme mitjançant una solemne processó en la qual van prendre part les comunitats de preveres i caputxins, l'Ajuntament, les confraries amb les banderes respectives i el cor de música de Sabadell i de Terrassa. Sota pal-li, hi anava la custòdia en mans del provincial de les Escoles Pies de Catalunya, el R. P. Pere Ferrer de S. Desideri i altres autoritats religioses, mentre sis nens que anaven vestits «en traje de angelitos» escampaven flors. Seguia la processó, amb un penó gran, el batlle general del Reial Patrimoni de Catalunya, Dn. Manuel Ibarra. També duien el seu penó tres nens de l'escola:

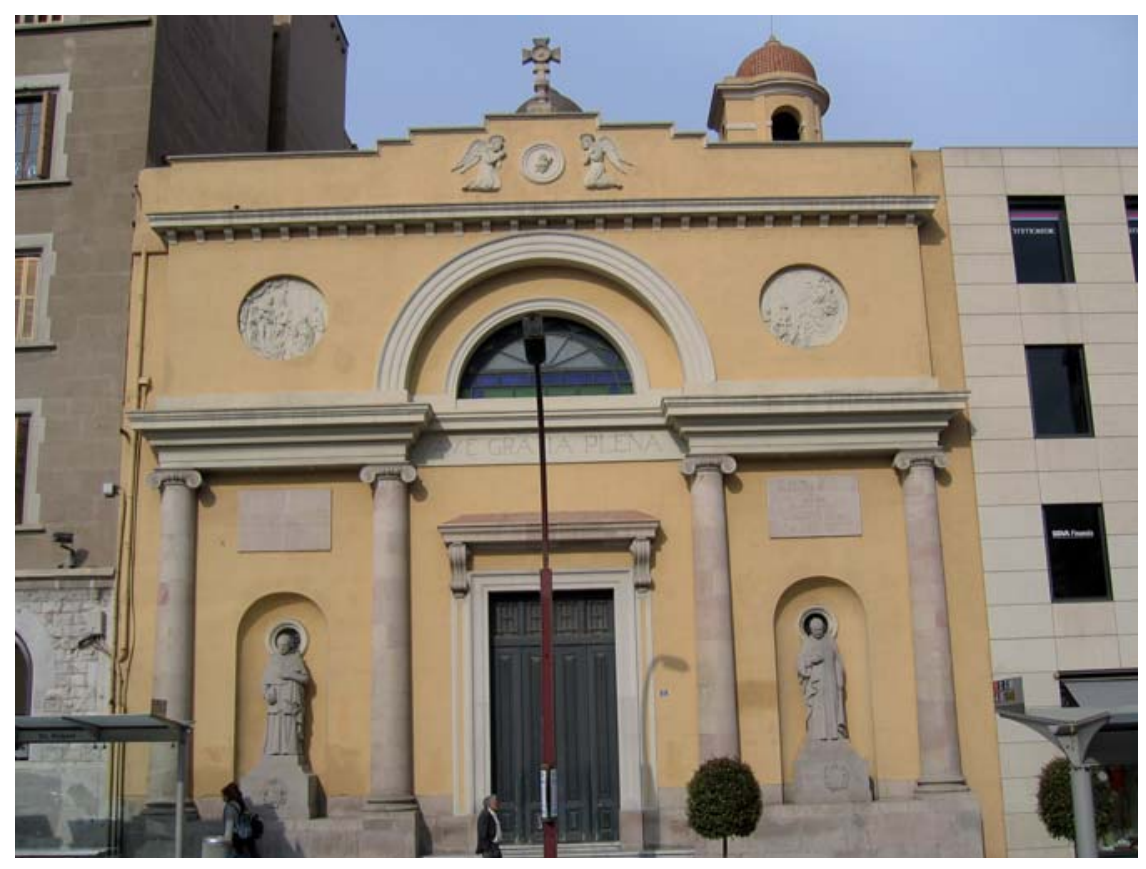

Figura 4.

Façana de l'antiga església dels escolapis de Sabadell (avui dels pares claretians).

[...] asistiendo los demás asociados que sus maestros con luces y no poca comitiva de gente de Sabadell y comarca, cantándose villancicos en el curso y no cesando el retoque de campanas. Entrada la procesión en la iglesia, celebró la misa solemne el P. Provincial con los mencionados asistentes, siendo el orador el P. Pedro Freixa, consultor Provincial y Rector del Real Colegio de Barcelona, quien se lució mucho con su bien tejido sermón muy tierno y pío y el más adecuado al objeto, siendo de los infinitos oyentes el más aplaudido. Concluída la Misa la música cantó un solemne Te Deum, en acción de gracias y para implorar las bendiciones del cielo para S.M. y Real Familia, y dada la bendición con el Santísimo se dió fin a la función.

Un cop acabat i beneit l'edifici, el mateix quadern de notes del pare Miret conté els noms dels principals artífexs materials de la construcció del temple, així com les quantitats monetàries que havien percebut fins al 6 de maig de 1832 . Com a arquitectes, hi figuren Antoni Cellers, seguit dels noms d'Alañó i Fontseré - pensem que aquest últim es refereix a Josep Fontseré i Domènech, que trobarem més tard com a autor del projecte de l'església parroquial de Pallejà. Fins a la data assenyalada anteriorment (maig de I 832), els tres arquitectes havien percebut la quantitat de 27.656 lliures ${ }^{31}$.

Aquesta església ha esdevingut l'obra més emblemàtica de l'arquitecte Cellers -bàsicament, perquè és l'única de les que va fer que es conserva
30. APEPC: A-IV-1. Libro que contiene los Datos relativos a la construcción de la iglesia, foli 94.

31. "Como canteros figuran Pedro Casals y Josep Martell, que habían percibido hasta ese momento la cantidad de 33.652 libras, mientras que el molero Francisco Campí había recibido 7.975. Los carreteros Gaspar Rozes, Cuberta y Morlius, 11.736 libras. A los carpinteros y herreros Pere Puig, Josep Valls, Francesc Mutiñó y Francesc Brusi se les había pagado hasta entonces 8.790 libras. Como pintores y escultores figuran los nombres de Ferreri, Francisco y Salvador Mayol, que habían percibido la cantidad de 25.860 libras. Finalmente, figuran los pagos de 3.200 libras al sastre Girabau y 2.249 libras a Isidre Pallés por la campana. El cálculo total de la obra se estimaba en ese momento en 25.000 duros.» 


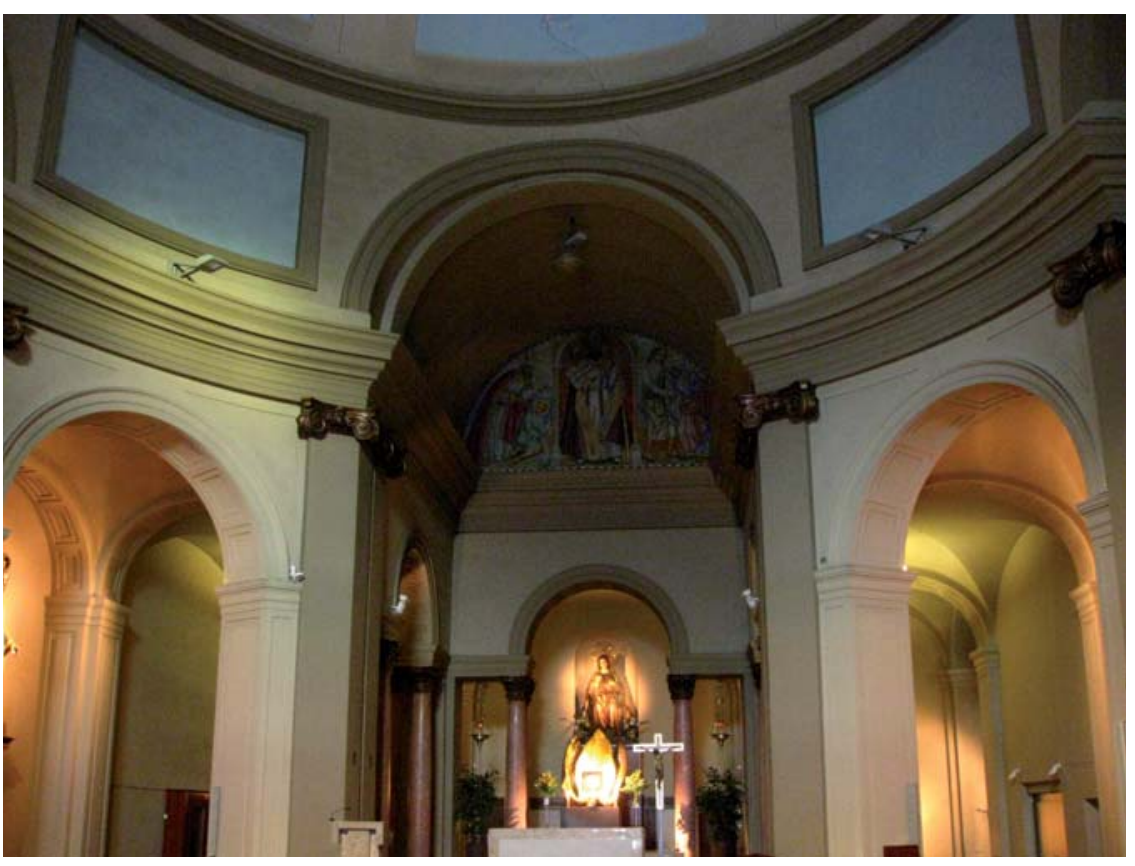

Figura 5.

Interior de l'antiga església escolàpia de Sabadell (Vallès Occidental).

32. Josep Renart va escriure, entre 1808 i 1810 , unes memòries professionals amb el títol de Quincenarios, adreçades al seu fill, qui esdevindria arquitecte $\mathrm{i}$ escriptor teatral Francesc Renart i Arús. Aquests «quinzenaris» eren sis quaderns en els quals Renart i Closes tenia el propòsit i l'ambició de plasmar tots els seus coneixements professionals per tal de transmetre'ls al seu fill, de manera que aquest pogués encarar-se amb professionals més experimentats. Els quinzenaris havien d'esdevenir, doncs, un complement dels tractats dels manuals existents, una llibreta de secrets, un codi deontològic moral, unes memòries personals i un testament profesCOROMINA, La construcció en l'arquitectura de Barcelona a final del segle XVIII (tesi doctoral inèdita), Barcelona, Universitat Politècnica de Catalunya, 1996). En definitiva, també constitueixen un testimoni de primera mà sobre el que, a començaments del segle XIX, un mestre de seixanta anys pensava que una persona havia de saber per fer de mestre de cases $\mathrm{i}$ arquitecte.

33. La revista Arraona (15, II època, tardor de 1994, Sabadell) fa referència a un trebal de l'abans esmentat professor de I'ETSAB. Aquesta cita l'he localitzat en un treball de curs realitzat per Montserrat Ezquerra, pe l'assignatura d' "Art Català Modern", que imparteixo a la UAB íntegrament. La façana s'inspira en la sobrietat i el monumentalisme de l'arquitectura renaixentista italiana, s'estructura mitjançant un arc de triomf dividit horitzontalment en dos pisos a través de cornises. Verticalment, l'església presenta tres cossos de gran simetria, els laterals flanquejats per columnes jòniques a la part inferior, mentre que a la part de dalt hi figuren dos medallons decorats amb relleus. El cos principal està ocupat per la senzilla porta d'entrada i per un arc de mig punt a la part superior.

La planta ovalada - més per una qüestió pràctica d'espai i de visualització, que no pas d'especulació de caràcter estètic - $s$ 'ha de relacionar amb exemples deutors del barroc, com l'anteriorment esmentada església del Carme Calçat, més relacionable amb exemples del barroc berninià, recollits en un primer moment per l'academicisme hispànic, com ho palesen les obres primerenques de Ventura Rodríguez - hem esmentat la madrilenya parròquia de San Marcos i podríem afegir-hi (si bé l'autoria de Rodríguez encara és només una atribució) la capella de Sant Narcís de la col-legiata de Sant Feliu de Girona.

Però l'interior de l'església sabadellenca no deixa de transmetre la innegable influència palladiana, tant en voga durant el primer terç del segle XIx. Pensem que un dels primers "pal·ladians» confessos havia estat el mestre d'obres Josep Renart i Closas, que manifesta la seva admiració per Palladio (juntament amb Francesco Milizia) en els seus Quinzenarios, escrits entre I808 i i 8 I0 i dirigits al seu fill, Francesc Renart i Arús, qui en prendrà bona nota, com veurem en els projectes per a les esglésies de Sant Feliu de Llobregat o Santa Maria de Sants ${ }^{32}$.

A Josep Renart, l'admiració per Palladio li venia del coneixement que tenia dels quatre volums que, amb el títol de Le Fabbriche e $i$ Disegni di Andrea Palladio, va publicar Ottavio Bertotti Scamozzi a Vicenza entre I776 i I783. Renart, després de qualificar Andrea Palladio de «príncep dels arquitectes», afirmava que en tots els seus edificis «se ve la profundidad de ideas y ornatos que había en este célebre hombre, porque la mayor parte de ellos están con un gusto muy elegante, causando mucha gravedad por su coordinación tan brillante de todas sus partes, y pueden sacarse de ellos mucha enseñanza y muy copiosas ideas». Si bé en temps de Renart i Closas la difusió del tractat pal-ladià a Catalunya encara era força recent, pensem que en temps d'Antoni Cellers ja devia ser plenament consolidada, de manera que fins i tot devia arribar a desplaçar el sempitern Vignola, que havia estat el manual de referència dels mestres d'obres sense títol. Així doncs, prendre el tractat de Palladio com a referència no era només indicatiu d'una «moda»-com podria ser-ho el neopal-ladianisme anglès, si bé la referència pal-ladiana sempre havia estat a la base de la tradició arquitectònica britànica d'època moderna (des d'Inigo Jones fins a Christopher Wren), molt abans de les reedicions pal-ladianes en anglès al segle Xviri i de la publicació del Vitrubius Britannicus (entre I7Is i I72s per Robert Campbell, que també publicarà l'any I729 la seva interpretació dels Andrea Palladio's Five Orders of Architecture), que suposarà l'eclosió absoluta amb les obres del propi Campbell o de Lord Burlington. En el cas català, l'adopció «madura» de Palladio - pensem que la primera edició castellana d'Ortiz y Sanz no havia aparegut fins l'any I797- respon també a un nou concepte d'arquitecte, ja molt més teòric i amb formació específica, capaç d'interpretar la complexitat més gran del tractat pal-ladià respecte al «llibre d'imatges» que era bàsicament el tractat de Vignola.

A l'església escolàpia de Sabadell, la referència als dibuixos de Scamozzi sembla indiscutible, atès que arriba a suggerir la influència de la capella de la pal.ladiana vil.la Barbaro, construïda a Maser l'any I 580 . D'una banda, l'alçat interior s'estructura segons el mòdul utilitzat a la façana de l'església escolàpia de Sabadell; de l'altra, les dues torretes de la mateixa capella o tempietto Barbaro fan pensar a l'arquitecte Enric Granell ${ }^{13}$ que inicialment també se n'haurien projectat dues a Sabadell, encara que finalment només se'n va arribar a construir una. Amb tot, la torreta campanar de Sabadell presenta moltes semblances amb el tipus de torre de la capella Barbaro, alhora que seria del mateix tipus que la que apareix al projecte de l'església de les Preses, així com als exemples anteriors de l'ermita del Remei d'Alcover i l'església del Miracle a Balaguer. 
En el cas del projecte neoclàssic de les Preses - obra de l'acadèmic Eusebio Maria de Ibarreche i malauradament irrealitzat-, s'evidencia el fet que l'element més important és el pòrtic columnat i no pas el campanar, que té un paper molt secundari i reculat respecte a la façana principal, una mica com el que succeeix a Sabadell. De manera que nosaltres ens inclinem més a pensar que no s'haurien pas projectat campanars bessons - com sí que hauria fet Cellers, en canvi, en el segon projecte de l'església del Vilosell-, sinó que el campanaret existent era l'únic necessari per acomplir el servei preceptiu.

Finalment, mitjançant la comparació amb imatges més antigues, es veu que, en el moment de la construcció, el carrer es trobava a un nivell més baix, de manera que hi haurà una graonada de cinc escales fins a la porta d'accés, la qual cosa contribuirà a accentuar la monumentalitat de tot el conjunt.

\section{L'ombra allargada de}

\section{l'Acadèmia: precedents $\mathrm{i}$} influència de l'arquitectura religiosa d'Antoni Cellers

Si ens fixem en la façana com a element més representatiu i definitori de l'estètica neoclàssica en l'arquitectura religiosa - ja que les plantes o la decoració interior d'aquests temples no difereixen pas gaire de la gran majoria de solucions anteriors, sigui mantenint l'esquema d'una sola nau longitudinal amb capelles laterals, sigui segons el model (recuperat al segle XVIII) de la planta de saló-, el principal antecedent pel que respecta a les façanes academicistes d'arquitectura religiosa el trobem a la zona de Tarragona, concretament, a l'església parroquial de Vilallonga del Camp, construïda segons el projecte de l'acadèmic Miguel de Toraya. La referència a aquesta església parroquial d'aquest poble de la comarca del Tarragonès hauria de resultar almenys insòlita, si tenim en compte els nombrosos edificis d'una importància superior - pel que fa a envergadura i monumentalitat - de l'arquitectura de l'últim terç setcentista. El cas és, però, que aquests edificis, com les noves catedrals de Lleida o Vic, no responen als models preferits per les directrius acadèmiques: en el cas de Lleida, la nova catedral recrea a la façana un model de porxo o atri amb arcades que recorda el de l'església de Sant Agustí Nou, a Barcelona, mentre que la nova catedral de Vic, amb el suposat projecte del mestre d'obres Josep Morató i Codina, anirà per uns altres viaranys sense gaires bons resultats. És per això que, des de la historiografia de l'art català, hom podria creure que, per cercar un antecedent academicista modèlic dins les últimes dècades del segle anterior, a Catalunya ens hem de remetre només a l'església tarragonina ${ }^{34}$, profusament estudia- da per Anna Serra i Masdéu ${ }^{35}$. Però veurem com el pòrtic d'inspiració clàssica, els medallons amb relleus o el projecte (inacabat) de dos campanars del projecte de Vilallonga no és pas un fet aillat dins l'arquitectura projectada a la Catalunya del darrer terç del segle xviII.

De fet, un estudi de Cadiñanos Bardeci aparegut al Boletín del Museo Camón Aznar l'any 2005 va posar de manifest nombrosos projectes d'esglésies catalanes de l'època que es conserven als fons documentals pertanyents al Real Consejo, a l'Archivo Histórico Nacional de Madrid. L'article reproduïa nombrosos projectes realitzats per acadèmics, que intentaven «subsanar» els que havien realitzat, sense «atenerse a los principios básicos de la buena arquitectura», els mestres d'obres locals. El visionament d'aquests dibuixos ens descobreix projectes que es troben perfectament en la línia del de Vilallonga - podríem citar exemples com el d'Ulldecona (realitzat el I79I per Bartolomé Ribelles) o fins i tot el més modest de Pere Albrador per a l'església de Tortellà, amb una portada de regust perfectament clàssic que finalment tampoc no es va construir. Cal assenyalar, però, que alguns d'aquests projectes fins $\mathrm{i}$ tot superen en pretensions classicistes el de Vilallonga, com el que Eusebio Maria de Ibarreche realitza per a les Preses, presidit per un gran pòrtic amb columnata dòrica i frontó triangular, on tan sols s'obriria un òcul ovalat que actuaria com a rosassa.

Ara bé, com hem dit fins ara, la diferència d'aquests projectes amb el de Vilallonga és, fonamentalment, que no s'arribaren a materialitzar en la major part, per la qual cosa aquesta església tarragonina quedà com un dels escassos exemples «d'èxit» de l'Acadèmia - un altre, menys conegut, seria el de l'església de Torrefarrera, on el projecte de l'acadèmic Antonio Losada va imposar-se al projecte més «tradicional» d'Isidre Roigé, qui, malgrat la solució acadèmica, es va haver d'enfrontar de bon començament a l'oposició dels veïns, que el devien trobar «pobre» $\mathrm{i}$ «poc sumptuós».

Però si encara cerquem antecedents més immediats de l'església de Sabadell en els quals s'evidenciii la depuració neoclàssica, hem de referir-nos - sempre dins el context d'artífexs que hagin realitzat obres d'arquitectura religiosa - a Francesc Renart y Arús (I783-I852), autor dels projectes de les esglésies de Sant Feliu de Llobregat (I 82 II 824) i Santa Maria de Sants (I 828). Home polifacètic, dedicat a l'arquitectura, a l'urbanisme i al teatre, va ostentar càrrecs de caràcter tècnic, com a arquitecte substitut al Tribunal Real Ordinario, càrrec del qual fou destituït i posteriorment readmès després d'haver obtingut el títol d'arquitecte l'any I $830^{36}$.

Les esglésies de Sant Feliu i de Sants constitueixen bells exemples de neoclassicisme anteriors a l'església escolàpia de Cellers. S'hi introdueixen
34. Això no vol dir que deixem de banda l'empremta de Ventura Rodríguez a Catalunya, des de l'obra del Collegi de Cirurgia fins als hospicis d'Olot i Girona, on també de ben segur va projectar la capella de Sant Narcís a l'església de Sant Feliu. Amb tot, Rodriguez no deixa un prototip de façana d'església a Catalunya, com sí que en deixa un a Pamplona, on projecta la nova catedral amb un pòrtic amb columnes i frontó, dues torres per banda i cúpula.

35. A. Serra Masdeu, «L'església parroquial de Sant Martí de Vilallonga del Camp», Locus Amoenus, 4. Universitat Autònoma de Barcelona, 1998-1999.

36. F. Fontbona, Història de l'art català, volum vi, Barcelona, Edicions 62, 1983, p. 53. 
37. BC: Fons Renart. Lligall XVIII (4).

38. RABASF: Legajos (2-33-4)

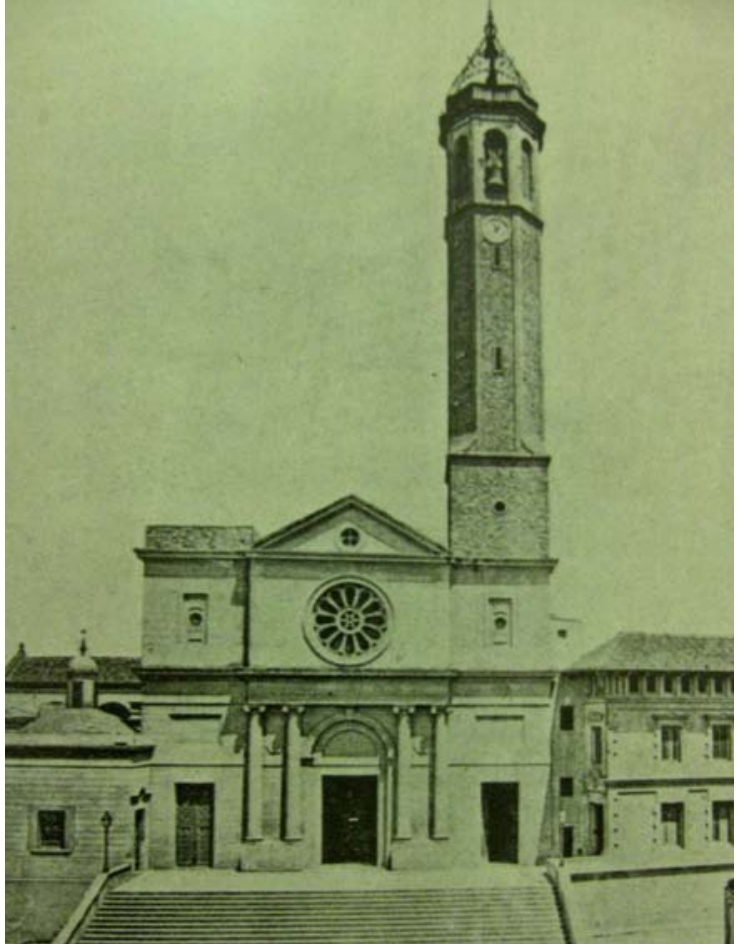

Figura 6.

Antiga església de Santa Maria de Sants (Barcelona), abans de 1936. Fontbona, F: «Del Neoclasicisme a la Restauració (1808-1888)» vol. VI de la Història de l'Art Català. Barcelona: Edicions 62, 1983.

elements que es repetiran després en aquella, com és el cas de l'arc serlià o la finestra termal o pal-ladiana, recuperada pels projectes academicistes, ja que anteriorment només s'havia fet present en l'arquitectura renaixentista de Pere Blai - concretament, en les finestres de les capelles bessones de Sant Joan i Sant Fructuós de la catedral de Tarragona.

Les dues esglésies - Sant Feliu i Sants - es divideixen horitzontalment en dos cossos mitjançant una potent cornisa i verticalment en tres, el central culminat per un frontó triangular. El projecte de totes dues esglésies contemplava un campanar de torre a tots dos costats -l'església de Sant Feliu no es va arribar a alçar segons aquest projecte $\mathrm{i}$ a la de Sants només es va construir un campanar, cosa que es va fer en una data molt posterior. Al'església deSanta Maria deSants - la construcció de la qual fou adjudicada, sota la direcció de Francesc Renart, als «fadrins mestres de casas» Josep Nolla, Jaume Solà i Llorenç Tulla ${ }^{37}-$, s'hi obre una rosassa a la façana, mentre que a Sant Feliu, aquest mateix lloc l'ocupa una finestra pal-ladiana. Precisament aquest tipus d'obertures - inscrites dins d'un arc serlià o preses directament de Palladio- constituiran un dels motius més recorrents i distintius d'aquesta arquitectura neoclàssica vuitcentista.

També podem pensar que s'hauria aproximat a aquesta influència neoclàssica l'església de Sant Andreu del Palomar, si s'hagués realitzat segons

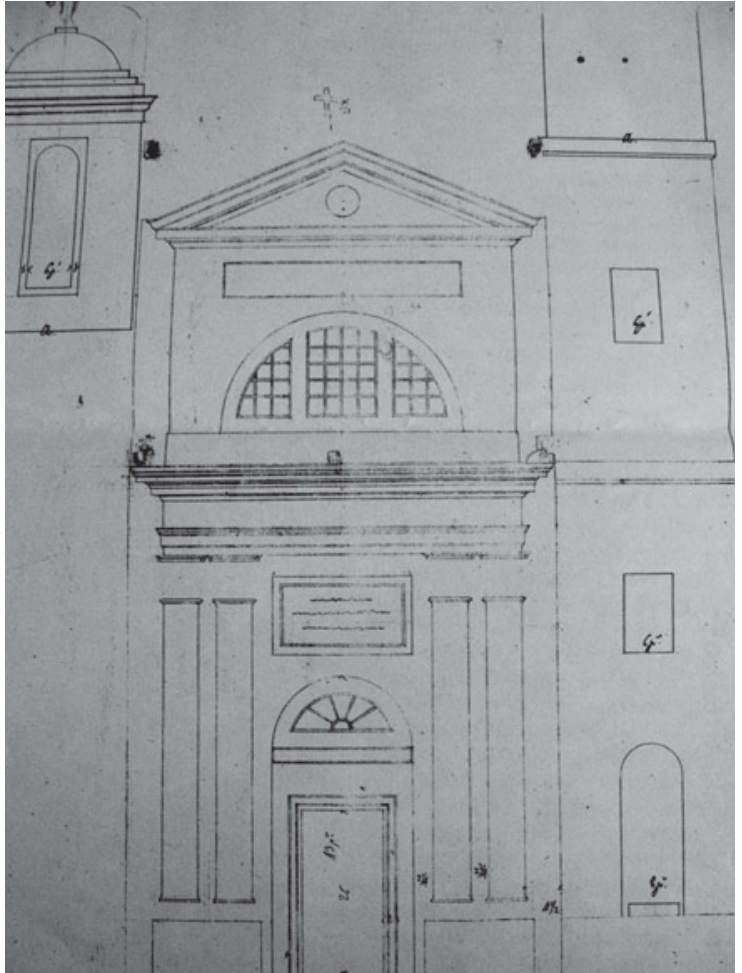

Figura 7.

Dibuix de Francesc Renart per a l'església de Sant Feliu de Llobregat (Baix Llobregat). BC: Fons Renart.

el projecte de Pere Serra i Bosch, tinent coronel agregat de capità a l'Estat Major, acadèmic de mèrit de l'acadèmia de Sant Carles de València i «arquitecto por S.M. de la Hacienda Nacional de este Principado y del Gobierno superior político del mismo", qui, conmogut pel deplorable estat de l'església parroquial de la població de Sant Andreu del Palomar, determinà fer un plànol ell mateix (gratis, especifica), per tal que fos valorat per l'Acadèmia, segons la carta de 25 de gener de I 822 dirigida a Martín Fernández Navarrete, secretari de la Real Academia de San Fernando ${ }^{38}$.

La resolució de l'Acadèmia és la següent:

[...] mediante ser un proyecto preventi más análogo a el sitio de su destino, con cuyas advertencias juzga la comisión que la Academia puede prestar su aprovación si así lo estima conveniente.

Curiosament, el projecte que podria presumir-se com a definitiu, del mateix Pere Serra i Bosch, no fou aprovat fins deu anys més tard, el I 2 d'agost de I 832 , si bé l'any I 835 trobem que l'Acadèmia aprova el projecte de Josep Mas i Vila per a la parroquial de Sant Andreu, així com un projecte del mateix artífex per a una capella de la comunió a l'església de la Pobla de Lillet, de la qual el propi Josep Mas exposa que: «se ha adaptado el órden jónico para la nave de la capilla, a fin 


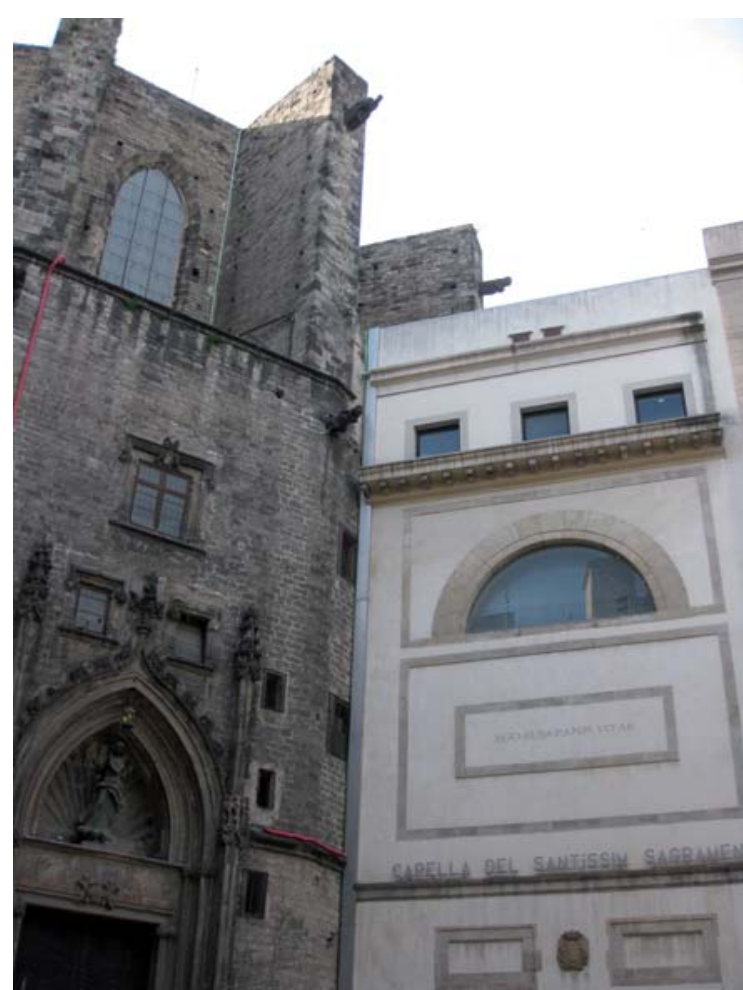

Figura 8.

Capella de la Comunió o del Santíssim de Santa Maria del Mar (Bar-

de que resalte más el sencillísimo altar de orden corintio, por ser el punto objecto de veneración de los fieles». Pel que respectava al projecte per a l'església de Sant Andreu, Mas havia procedit:

[...] adaptando el orden corintio tanto para la fachada como para el interior. Los bajos relieves del exterior seran alusivos a la vida del Santo titular, y los de la parte superior de los arcos de las capillas laterales corresponderán a los patrones de varias cofadrías o congregaciones que existen en el pueblo, a cargo de las cuales corresponde la conservación y aseo de sus altares respectivos.

El orden compuesto se adopta para el altar mayor, porqué siendo este el orden más sublime, le corresponde de indispensable obligación colocarse en el objecto principal. Se pretende construir el campanario en el testero del edificio para que la fachada no presente monotonía en su vista, pues que si bien en el alzado geométrico se descubre una porción de aquel en el centro de la cúpula, ambos se desvanecerán cuando esté construído el edificio.

Aquest projecte tampoc no serà el que es durà a terme; el temps passava $\mathrm{i}$ arribaven gustos estètics nous, de manera que, finalment, serà Josep Domènech i Estapà qui donarà la fesomia definitiva a l'església l'any I 88 I, el qual, juntament amb
Pere Falqués Urpí, hi introduirà un cert aspecte bizantinitzant.

Sí que ha arribat, en canvi, fins als nostres dies, el resultat del projecte de Francesc Vila per construir la capella de la Comunió per a l'església de Santa Maria del Mar de Barcelona, que fou aprovat per l'Acadèmia el 4 d'octubre de I 83 I i construida entre I 832 i I $834^{39}$.

Es tracta d'una construcció afegida a la magnífica església gòtica per la part absidal, on emergeix una estructura de la qual destaca la gran finestra neopal-ladiana com a distintiu, mentre que a l'interior està coberta amb volta de canó delimitada per arcs faixons que enllacen amb grans pilastres d'ordre compost.

El cas és, però, que aquesta obra no estigué exempta de polèmica, ja que, l'any i 834, Francesc Vila, en una carta als obrers de Santa Maria del Mar, els acusa de malmetre el projecte, en una actitud que ens hauria de recordar força l'abisme sovint existent entre el gust acadèmic i el gust del poble. Vila s'expressa, dolgut, en aquests termes:

En efecto ustedes se acordarán que después de haberles presentado mi proyecto y merecido la aprobación de ustedes, pasóa la censura dela Real Academia, la que pronunciando un fallo favorable, me puso a cubierto de la crítica y de la mordacidad. Esto no obstante creyéndose ustedes autorizados para ejercer un absolutismo des- medido por el papel que representaban, trataron de desfigurar el proyecto, pretextando que como señores de obra, debía yo ceñirme al gusto antojadizo de ustedes, a lo que me opuse abiertamente, alegando cuantas razones facultativas me sugieren mis cortos conocimientos. Los preceptos del arte fueron graduados de nimiedades; las proporciones y las formas, de quimeras; la rigurosa observancia del plano, de etiquetas $[\ldots]$.

Por último el escandaloso paso que acaba de darse no ha podido menos que herir mi pundonor. La parte del ornato que puede considerarse como el alma de una fábrica, ha sido confiada a la arbitrariedad de escultores adocenados, no obstante de haber yo presentado los modelos de las formas que precisamente exigía la majestad del objeto ${ }^{40}$.

En definitiva, Francesc Vila acaba anunciant que s'enretira del projecte i se'n desentén, al mateix temps que declara que es reserva el dret d'informar la Real Academia de San Fernando sobre el que havia passat, sense que, a partir d'aquest punt, disposem d'informació que ens permeti saber com va acabar l'assumpte.

Unes altres esglésies construïdes a prop de Barcelona van ser les de Molins de Rei i Pallejà, totes dues a la comarca del Baix Llobregat.
39. J. BAssegoda, Los maestros de obras de Barcelona, Barcelona, Editores Técnicos Asociados, 1973, p. 26. D'altra banda, també Francesc Vila presentà, el mes d'octubre de 1832, un altre projecte per realitzar una capella per al cementiri de Manresa, projecte aprovat el 16 de desembre del mateix any.

40. BNC: Fons Renart. Lligall $\mathrm{LV}, 3$. 
41. RABASF: Legajos (2-33-5)

La vila de Molins de Rei ja havia vist néixer, durant les primeres dècades del segle xix, projectes importants com l'anomenat Real Canal de la Infanta. L'any I 827 , s'havia fet un primer intent de construir una església nova, amb plànols de Josep Mestres i Gramatxes, que ja era arquitecte per la Real Academia de San Fernando, pare de Josep Oriol Mestres i Esplugas i membre d'una de les nissagues més importants de mestres de cases barcelonins d'origen gremial. Mestres envià el projecte a la Real Academia de San Fernando el 26 d'octubre de $1832^{41}$, i la resolució de la comissió d'arquitectura hi fou favorable el 4 de novembre del mateix any.

L'arquitecte Josep Mestres enviava, juntament amb els plànols, l'explicació següent sobre el sentit i l'estil del temple:

Los templos han sido en todos tiempos los edificios que más han merecido la atención de los profesores de las bellas artes, dedicándolos en lo antiguo al culto de los Dioses que entonces adoraban, y en el día al culto divino de la religión católica que felizmente profesamos. Con tanto acierto serenísimo señor se esmeraron los célebres profesores antiguos en esta clase de edificios, que los más de ellos por su perfección sinó en el todo a lo menos en sus partes sirven de modelo a los modernos, adaptándolos y variándolos según conviene atendido el local que deben situarse y la mayor o menor grandiosidad que requieren por razón del número de población.

Sería muy fácil a los modernos formar esta clase de edificios si podían adaptar o por mejor decir copiar los muchos diseños antiguos que los Vitrubios, los Palladios, los Serlios nos han dejado en sus dignas obras, pero como es preciso sin separarse de las máximas de dichos autores formar los proyectos adaptándolos a las circunstancias de los pueblos que se destinan, resultan obras no del todo perfectas por no poder desarrollar sus ideas el profesor encargado, mayormente cuando recae en un pueblo corto y que deba este costearlo, pues en tales casos falta el gusto a los propietarios que deben aprobar la obra por carecer de los principios y conocimientos necesarios y principalmente faltan los caudales para su realización, cuyos motivos obligaron a cometer muchas mezquindades en los proyectos sin las cuales pocos se ejecutarían.

Con estas bases serenísimo señor se me ha encargado formar el proyecto que acompaño de una iglesia parroquial para el pueblo de Reynas, situado a la montaña distante de esta capital unos ocho leguas, capaz para contener mil personas en día de función extraordinaria, y atendido la cortedad de aquel pueblo, su si- tuación retirada y sobre todo la escasez de caudales para sufragarlo he proyectado ya desde las primeras líneas buscando la economía posible, comodidad y belleza a lo menos la más precisa, para cuyo fin he adaptado un paralelogramo rectángulo de I03 pies de largo por 7I pies de ancho y según las ideas de aquel pueblo la he trazado de una sola nave sin crucero con las capillas laterales pero sin comunicación interior una con otra como se me ha prevenido.

Está decorada dicha nave con pilastras del orden dórico de Marcelo con el correspondiente cornisamiento, cuyo orden por su gravedad y sencillez he considerado reunir las tres principales circunstancias de solidez, belleza y economía, aunque a fin de contener la dicha nave una suficiente altura he necesitado el auxilio de un zócalo de dos pies de alto que sigue alrededor de la iglesia, sobre el cual continua un contrazócalo de 3 pies y 9 pulgadas que rodea también el presbiterio por quedarse el primero a la línea de la gradería del mismo, aumentando la altura de las pilastras un semidiámetro o mitad del ancho para dar una mayor esbeltez a dicho orden, y sobre el cornisamiento termina un sotabanco de 3 pies y 9 pulgadas que remata el orden.

La referida nave está cubierta con una serie de bóvedas tabicadas apoyadas sobre del sotabanco a fin de proporcionar una mayor grandiosidad a la expresada nave.

El presbiterio está cubierto con una boca semicircular que forma la cuarta parte de una esfera para cubrir el nicho de planta también semicircular en el cual se colocarà el retablo mayor, adornando la dicha bóveda con casetones para más riqueza en aquel punto como a preferente y principal de la iglesia.

La puerta de la derecha del presbiterio comunica a la capilla destinada para la comunión separada enteramente de la concurrencia de la iglesia, dentro de la cual se colocarán los confesonarios como lugar más retirado y a propósito para la reconciliación, y a la puerta de la izquierda entra a la sacristía, sobre de cuyas puertas están marcados dos baxos relieves alusivos a las virtudes del santo, teniendo ambas piezas la entrada pública por las dos últimas capillas de la iglesia con el fin de evitar la concurrencia del presbiterio en los actos de celebración, consiguiéndose por dichas entradas la comunicación al detrás de dicho presbiterio, y se sube al camarín por una escalerilla privada.

No hay duda que nuestros autores tan sabiamente previenen ser defectuosos los coros en la entrada de los templos, debiendo colocarlos en el presbiterio, pero como en las parroquias de poblaciones reducidas solo hay el cura y 
ayudante a lo más para los oficios divinos, es indispensable (como lo verifican) que los mismos feligreses o seglares desempeñen las funciones en el coro, cuya circunstancia priva el colocarlos en el presbiterio y obliga la misma rutina situarlos en la entrada de la iglesia, como lo están todos generalmente.

En la entrada de la iglesia está situado a la derecha un espacio o capilla sencilla destinada para los bautizos, y a la izquierda una escalera capaz para la concurrencia del coro.

Parecerá impropio serenísimo señor a primera vista no ver marcadas en dicha iglesia las torres para las campanas, siendo circunstancia absolutamente precisa, pero atendiendo a que por la falta de caudales solamente se pretende construir una y muy sencilla, si esta se sitúa en la fachada u otro punto que tenga vista afeará el todo del edificio, así como si fuesen dos adornadas lo enriquecerían, a este efecto he proyectado colocar una sencilla separada de la iglesia que tenga comunicación por la sacristía, logrando de este modo no verse desde el frente principal por quedar cubierta con la casa del cura que debe construirse en aquel punto.

La fachada principal de la iglesia he procurado, teniendo muy presente la economía indispensable que tanto se me ha recomendado, reúna el menor adorno posible, sin faltar tampoco a la belleza necesaria que requiere, para cuyo fin he trazado un cuerpo resaltado con unas líneas horizontales que figuran las juntas de los sillares de todo el ancho de la nave, en el cual está situada la puerta con sus jambas adornadas de una pequeña moldura y cubierta con guardapolvo sostenido por dos cartelas, rematando la expresada puerta dos niños con los símbolos de la religión católica. Separa esta estado una faja sencilla que sigue alrededor del edificio, sobre de la cual continúa la pared de fachada marcando en ella una ventana semicircular según las formas de Palladio para dar luz al coro, y remata la fachada un frontón y pequeño cornisamiento ideal almohadillado, en cuyo frontón he señalado una abertura para circulación de aires en los maderos de la cubierta.

En los dos cuerpos laterales retirados de dicha fachada se marca en el primer estado unas ventanas prolongadas verticales con guardapolvos y cartelas que dan luz a la capilla de bautizos y a la escalera del coro, en las cuales deben colocarse las correspondientes rejas de hierro para evitar la introducción por dichos puntos desde la calle atendida su poca altura, y separa este estado del segundo una faja sencilla, cuyo segundo estado tiene únicamente la precisa altura para tapar la cubierta de las capillas, quedando rematados dichos dos cuerpos retirados por otra faja.

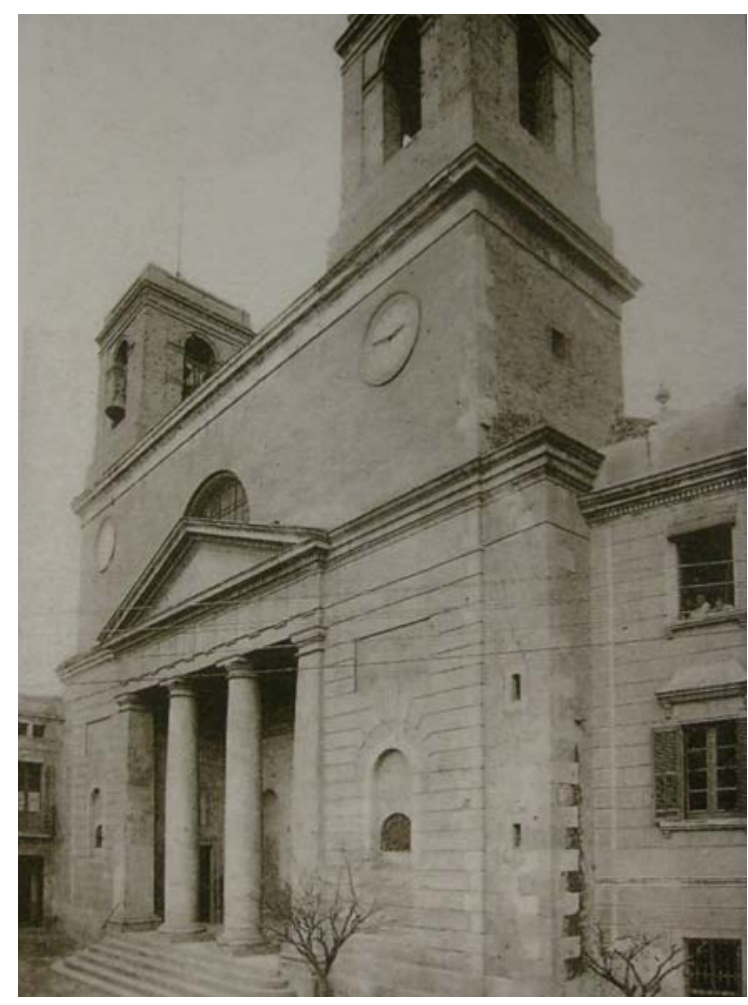

Figura 9.

Església antiga de Molins de Rei (Baix Llobregat), abans de 1936.

La armadura para la cubierta de esta clase de edificios es un punto de los más interesantes que requiere toda precaución y conocimiento a fin que reúna la solidez debida, pero como por sencilla que se proyecte siempre es de grande coste y está expuesta a las vicisitudes inevitables de la madera, he procurado y conseguido cubrir la referida iglesia sin necesidad de armadura alguna, continuando las paredes sobre de los arcos hasta la total altura formando los dos vertientes laterales en los cuales se colocarán los maderos o bigas necesarias para construir sobre ellas el correspondiente tejado; por cuyo método sencillo me ha parecido lograr el ahorro del grande coste que tendría la armadura y una mayor solidez en la cubierta.

No he dibujado los correspondientes estribos de los arcos de la iglesia por la mala vista que harían en el papel, desfigurando la facha$\mathrm{da}$, los cuales verificaré en la obra continuando las paredes divisorias de las capillas hasta la altura de dichos arcos, cuyas paredes, por ser muy retiradas de la línea de fachada, les privaría esta del punto de vista.

Esta es, serenísimo señor, la idea y método que me he propuesto en la presente obra, arreglada a la construcción de esta provincia, creyendo haber cumplido con el encargo que se me ha confiado, y esperando que teniendo V.A. en consideración que es una obra peque- 


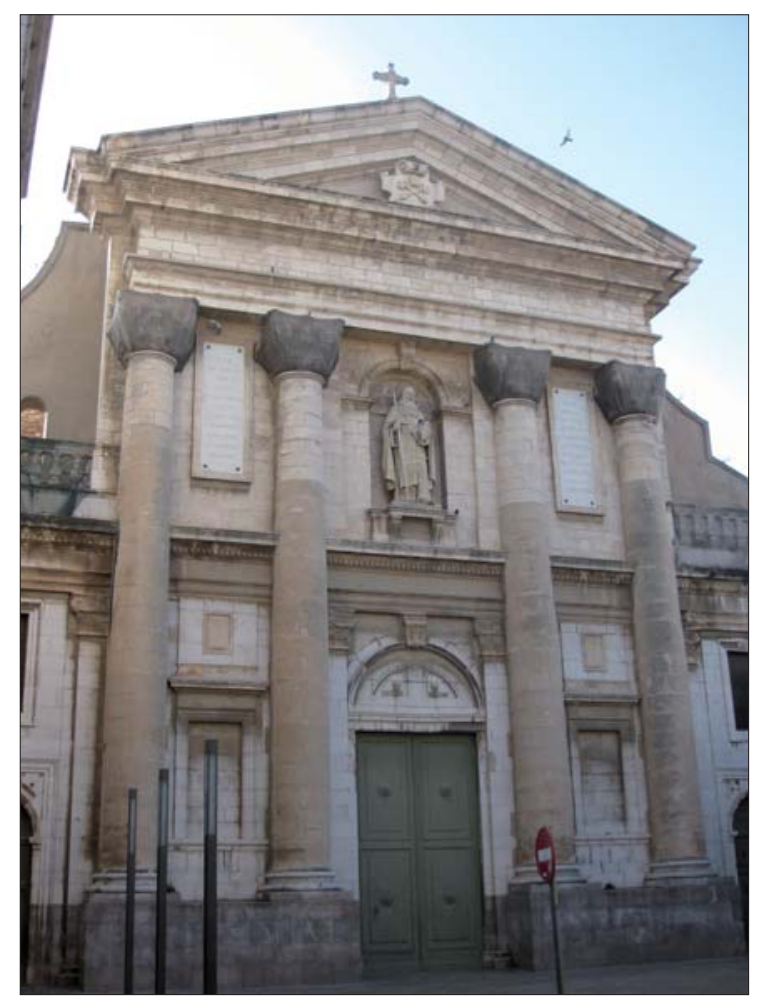

Figura 10.

Façana de l'església parroquial de Vilanova i la Geltrú (Garraf).

42. Bassegoda Nonell (1973, p. 85).

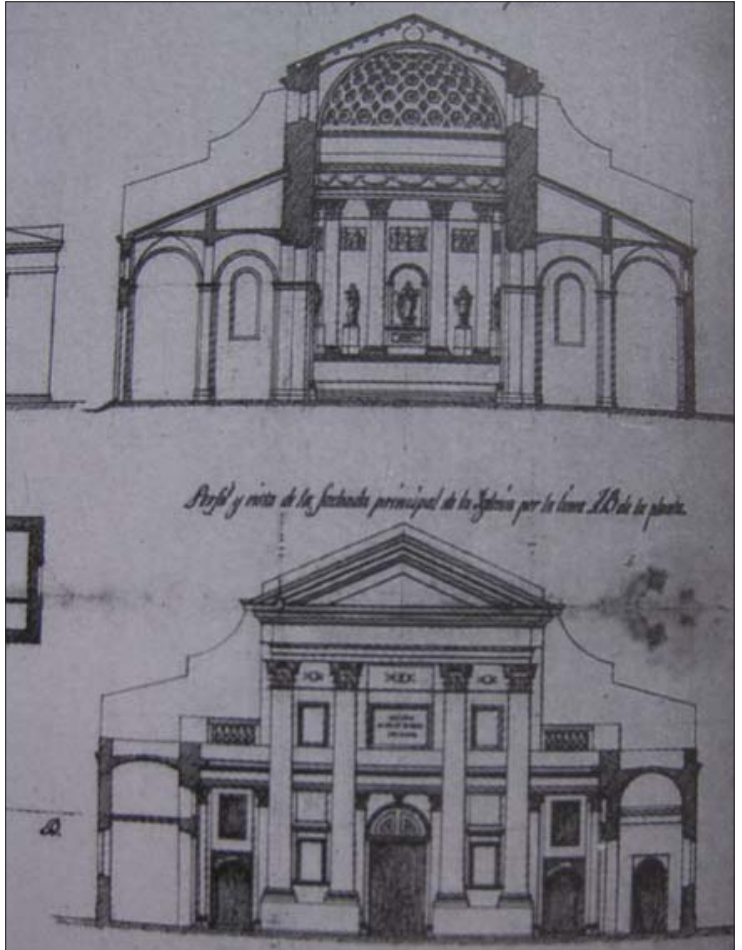

Figura 11

Projecte per a l'església parroquial de Vilanova i la Geltrú (Garraf), realitzat per Francesc Vallès l'any 1827. Font: Cadińanos 2005, 180.

la proximitat amb Sant Feliu de Llobregat, el ressò del primitiu projecte de Francesc Renart i Arús per a la seva església també hi és present.

Més bona sort tingué la veïna església parroquial de Pallejà pel que fa a la conservació. Dedicada a Santa Eulàlia de Mèrida, s'havia començat a construir l'any I 832 sota la direcció de l'arquitecte Joan Merlo - que havia rebut l'aprovació de l'Acadèmia per al projecte d'aquesta església en la junta del 27 de novembre de I83I-, però igualment fou interrompuda a causa de les guerres $i$ les vicissituds revolucionàries. Quan es van reprendre les obres - que es van acabar l'any I862-, igual que a Molins de Rei, l'arquitecte era un altre, en aquest cas, Josep Domènech i Fontseré, a qui hem vist col-laborant amb Antoni Cellers a l'església dels escolapis de Sabadell.

Sembla que el projecte irrealitzat de Renart per a l'església de Sant Feliu s'inspirava de manera més clara en l'església de Pallejà, tant per l'estructura de la façana - amb la preceptiva obertura palladiana-, com per la presència de dos campanars de torre. D'altra banda, però, hem de tenir present la col-laboració de Domènech i Fontseré amb Antoni Cellers a l'església de Sabadell, i, si bé les concomitàncies amb el temple sabadellenc no són tantes, ben segur que Domènech i Fontseré coneixia el projecte - que tampoc va materialitzar-seque Antoni Cellers havia realitzat per a l'església del Vilosell (les Garrigues), que sí que ens presen- 


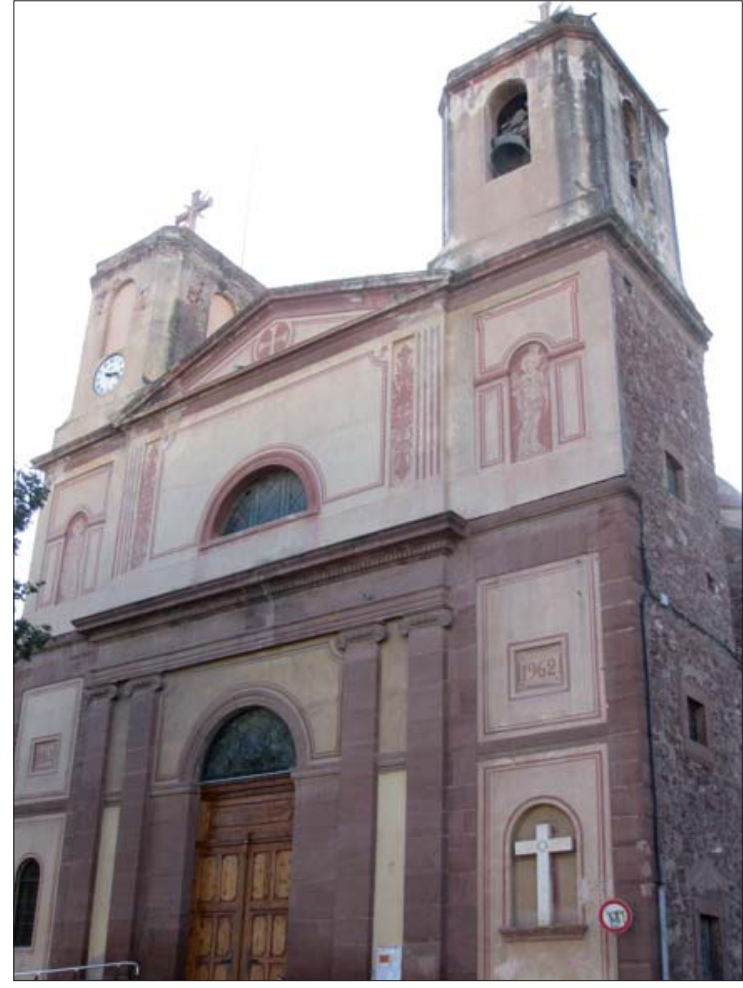

Figura 12.

Església parroquial de Pallejà (Baix Llobregat).

ta un temple amb dos campanars de torre, si bé l'accés es fa mitjançant un pòrtic amb columnes.

Un altre gran temple que podem denominar «neoclàssic» seria el de Vilanova i la Geltrú, per al qual Francesc Vallès presenta un projecte després que, l'any i 827, un llamp en malmetés la teulada i provoqués un incendi ${ }^{43}$. De l'església antiga, en restaria el campanar exempt, obra de fra Josep de la Concepció, mentre que el nou temple, concebut amb grans dimensions, presenta una façana amb un cos central articulat per un ordre gegant de pilastres compostes que unifiquen visualment els dos nivells horitzontals. El cos central és rematat per un frontó triangular, mentre que els laterals ho estan per una balustrada. Si n'examinem tant els dibuixos que es conserven com el resultat final de la façana, veiem com aquesta segueix clarament el model de l'església veneciana de San Giorgio Maggiore, obra d'Andrea Palladio ( I 566), si bé en el projecte de Vallès les dues columnes a banda i banda de la porta s'aixequen sobre un basament unificat i no sobre els altíssims podis individualitzats de l'església palladiana. A més, a Vilanova s'hi afegeixen uns braços sortints per banda, amb l'objectiu d'integrar el campanar del segle Xvir i que formarien, al seu torn, una mena de nàrtex que finalment no es va arribar a realitzar, amb la qual cosa el campanar va quedar exempt, com ho havia estat fins llavors.

L'interior, de tres naus amb capelles laterals, s'articula també mitjançant l'ordre compost, que es

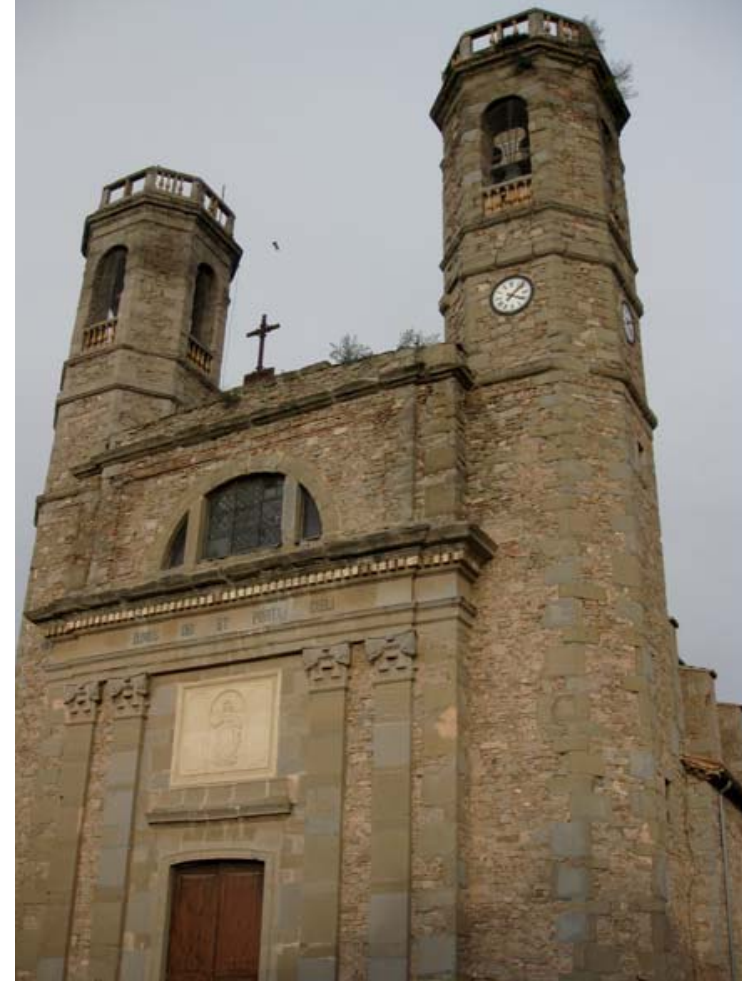

Figura 13.

Façana de l'església parroquial d'Olost (Osona).

perllonga a banda i banda de la nau fins a la conca absidal, rematada amb una volta de quart d'esfera cassetonada. En el projecte de Vallès es dóna una gran importància a l'aspecte decoratiu, amb garlandes i motius fitomòrfics que adornen les cornises.

D’altra banda, Pere Serra i Bosch presenta, l'any I 830, un projecte per construir l'església parroquial de Vilassar de Mar, que fou aprovat per l'Acadèmia el 4 de juny del mateix any. Seguidament, en presentà un altre per fer la renovació interior de l'església de Sant Boi de Llobregat, que fou aprovat per l'Acadèmia el 22 d'agost del mateix any ${ }^{44}$.

Finalment, encara dins les comarques barcelonines però més allunyats de la capital, en trobem interessants exemples a la façana de l'Institut Benèfic de Manresa, edificat entre i 857 i I $859^{45}$, i la façana de l'església parroquial de la població osonenca d'Olost, projectada per un jove Francesc Daniel Molina, que més tard es convertiria en arquitecte municipal de Barcelona i seria l'autor - entre d'altres i nombrosos projectes - de la urbanització de la Plaça Reial. Tots dos exemples - Manresa i Olost - es caracteritzen per la presència - absolutament predominant a la façana - de la finestra termal o pal-ladiana, que n'ocupa tot el cos superior. A un nivell inferior, la porta d'accés a l'Institut Benèfic de Manresa està inscrita dins una serliana, definida per columnes jòniques i una finestra d'arc de mig punt damunt la porta. Tot el conjunt està delimitat a la part superior per una cornisa que
43. RABASF: Legajos (2-335bis)

44. RABASF: Legajos (2-335bis).

45. Segons l'acta del 6 d'octubre de 1856, el fundador cedeix gratuitament un camp de regadiu situat dins del terme municipal de Manresa, a la partida de la Parada «en el cual campo previo permiso del cuerpo Municipa habrá de construirse el edificio arreglado al plan que se presenta aprobado ya por la Rea Academia de Barcelona, destinando la sobrante tierra para huerto y otros usos a utilidad del establecimiento. Al propio tiempo ofrece el fundador invertir por de pronto de dinero propio hasta la cantidad de ciento siete mil reales de vellon, en la construcción de una parte del edificio y proveherlo de muebles y ropas de todos usos para los veinte primeros pobres que se alberguen» (SARRET ARbós, Història de Manresa. Esglésies convents, Manresa, Sobrerroca, 1924, p. 293). 


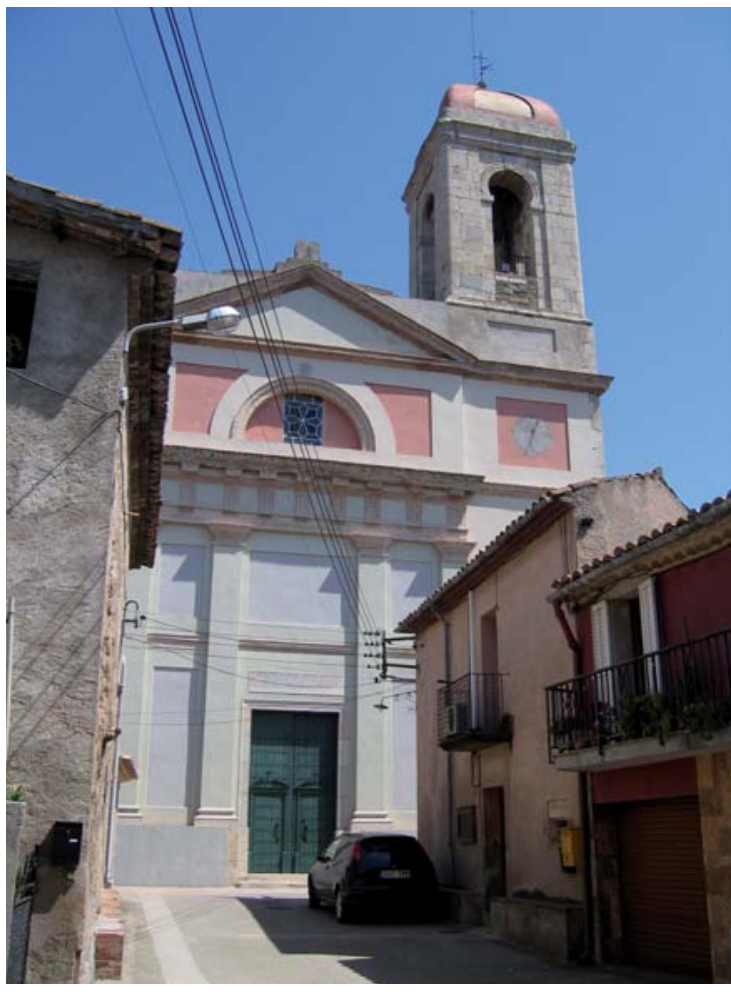

Figura 14

Església de Sant Joan de Mollet (Baix Empordà).

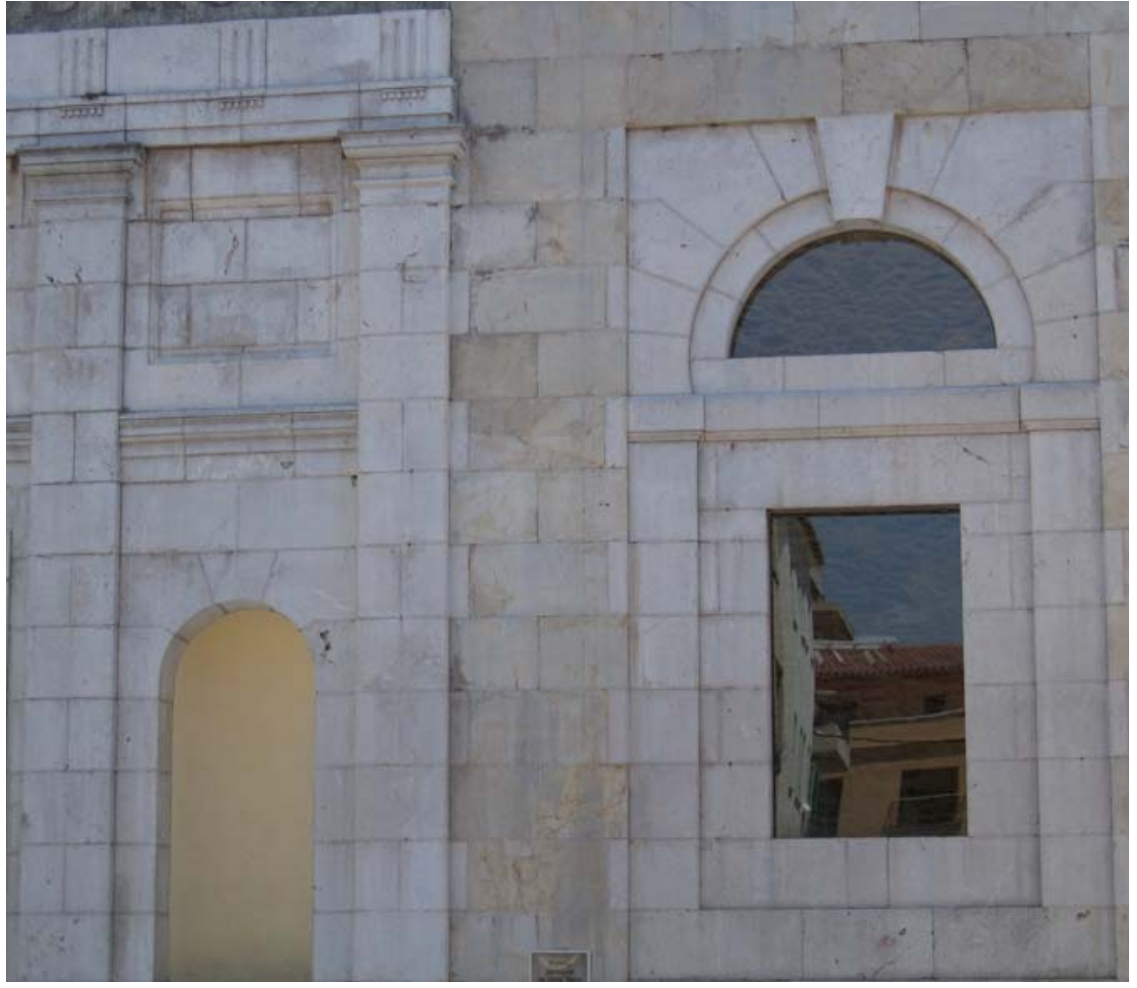

Figura 15.

Detall de la façana de l'església de Roses (Alt Empordà).
46. Vull agrair sincerament Francesc Miralpeix que m'hagués facilitat aquestes notícies de l'església de Sant Hilari Sacalm, procedents de l'arxiu parroquial i de la monografia L'església par roquial de Sant Hilari Sacalm. Monografia $i$ història per un sacredot de la vila (Santa Coloma de Farners, 1921). separa els dos cossos horitzontals de la façana. En canvi, la façana de Santa Maria d'Olost queda definida verticalment per les pilastres amb capitell jònic que flanquegen la porta d'accés a l'interior.

Encara més lluny de la influència barcelonina, les comarques gironines - $\mathrm{i}$, més concretament, empordaneses - ens aporten dos exemples remarcables de la mà d'un mateix arquitecte: Martí Sureda i Deulovol, autor dels projectes per a les esglésies parroquials de Sant Joan de Mollet (Baix Empordà) i almenys la façana de la inacabada església de Roses (Alt Empordà), si bé el temple s'havia començat durant l'últim terç del segle xviII. També segueix una línia semblant la façana de l'església parroquial de Sant Hilari Sacalm (Selva) . Tot i que la intenció de remodelar la façana ja es feia patent pels volts de 1808 , la realització va retardar-se a causa de la guerra i dels sempiterns problemes de finançament. Se sap que la construcció romànica persistí fins al I 836 , que la primera pedra de la nova façana es posà el i 8 de maig de i 856 i la construcció no s'acabà fins a la dècada de i 880 . Algunes notícies apunten l'arquitecte Francesc Vila com l'autor d'un plànol anterior que seria el que se seguiria, amb variacions, durant la reforma i l'ampliació ${ }^{46}$.

En dates més primerenques, però, tot just a començaments de segle xIx és quan trobem el projecte d'arquitectura religiosa neoclàssica més interessant (per bé que irrealitzat) de les comarques gironines, concretament, a la localitat de les Preses
(Garrotxa). Ja a finals del segle XvinI es documenta una gran controvèrsia al voltant de la construcció d'aquesta església: un cop rebutjat el projecte del mestre d'obres Pere Albrador i de resultar-ne insuficients les esmenes fetes per l'acadèmic Andreu Bosch - un dels pocs catalans que en aquell moment tenia el títol d'arquitecte i exercia a Catalunya-, serà el també acadèmic de San Fernando Eusebio Maria de Ibarreche qui, el mateix any I799, en farà un nou projecte.

En aquest projecte - els dibuixos del qual es conserven a l'Archivo Histórico Nacional-, es concebia la façana de l'edifici com un gran pòrtic clàssic, amb columnata dòrica - si fem cas del precepte serlià que aconsellava el dòric per als temples dedicats als pares de l'Església, la dedicació de l'església de les Preses a sant Pere hi fa especialment adient l'ordre dòric. La façana, doncs, estaria ocupada totalment pel pòrtic, conformat per un gran frontó triangular sostingut per un entaulament dòric - amb el preceptiu fris decorat amb tríglifs i metopes - aixecat, al seu torn, damunt de sis columnes. Aquest tipus de pòrtic esdevé l'expressió més prototípica del neoclassicisme arquitectònic, posada de manifest pel pòrtic que Ventura Rodríguez dissenya a la catedral de Pamplona o Julián Sánchez Bort a la catedral de Lugo (I769), mentre Silvestre Pérez, que l'any 1794 havia reproduït en un dibuix el panteó de Roma i el seu pòrtic, també l'aplica a l'església de Bermeo (I 807). 


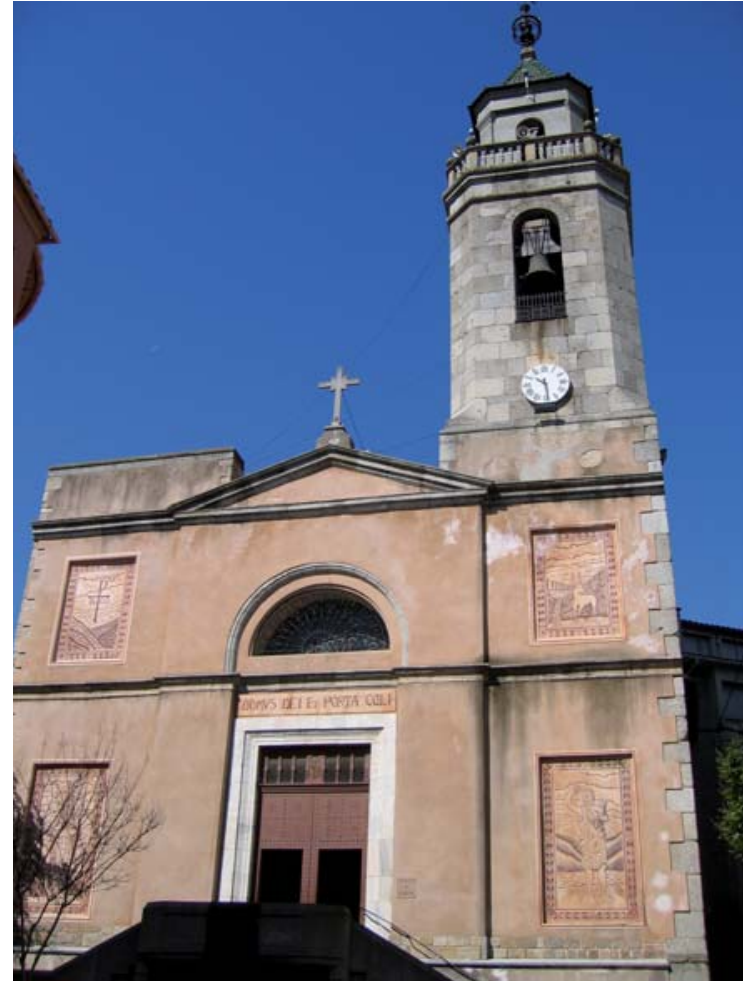

Figura 16.

Església parroquial de Sant Hilari Sacalm (La Selva).

Exteriorment, els laterals de l'església no presenten cap tipus de decoració, només tres obertures per banda aprofitant les llunetes de la volta. El campanar estaria situat a la zona de la capçalera, de base quadrada i petita torre circular, de manera molt semblant a un tipus de campanar poc habitual però utilitzat en petites esglesioles de l'últim terç del segle XviII, com l'anteriorment esmentada ermita de la Mare de Déu del Remei a Alcover (Baix Camp) i que també serà utilitzat per Antoni Cellers en el cas de l'església escolàpia de Sabadell. El projecte d'Ibarreche, però, rebé el dictamen següent per part de l'Acadèmia:

Y habiéndose reconocido con la mayor atención los mencionados planos ha sido de parecer la Academia: Que tratándose de conservar como es debido lo que se pueda de la obra ya ejecuta$\mathrm{da}$, no une bien con esta la que se intenta hacer de nuevo; que para proceder con economía no puede adoptarse este proyecto, el cual por su profusión ha de ocasionar gastos excesivos; que está muy escaso de luces, quedando las capillas del crucero totalmente sin ellas; que algunas partes del edificio no están bien combinadas y son inconstruibles, como el pórtico de la fachada, si hubiera de ser de cantería como parece; y que las armaduras sientan sobre las bóvedas así en la nave principal como en las laterales, lo que sería causa de ruina, por todo lo cual no puede

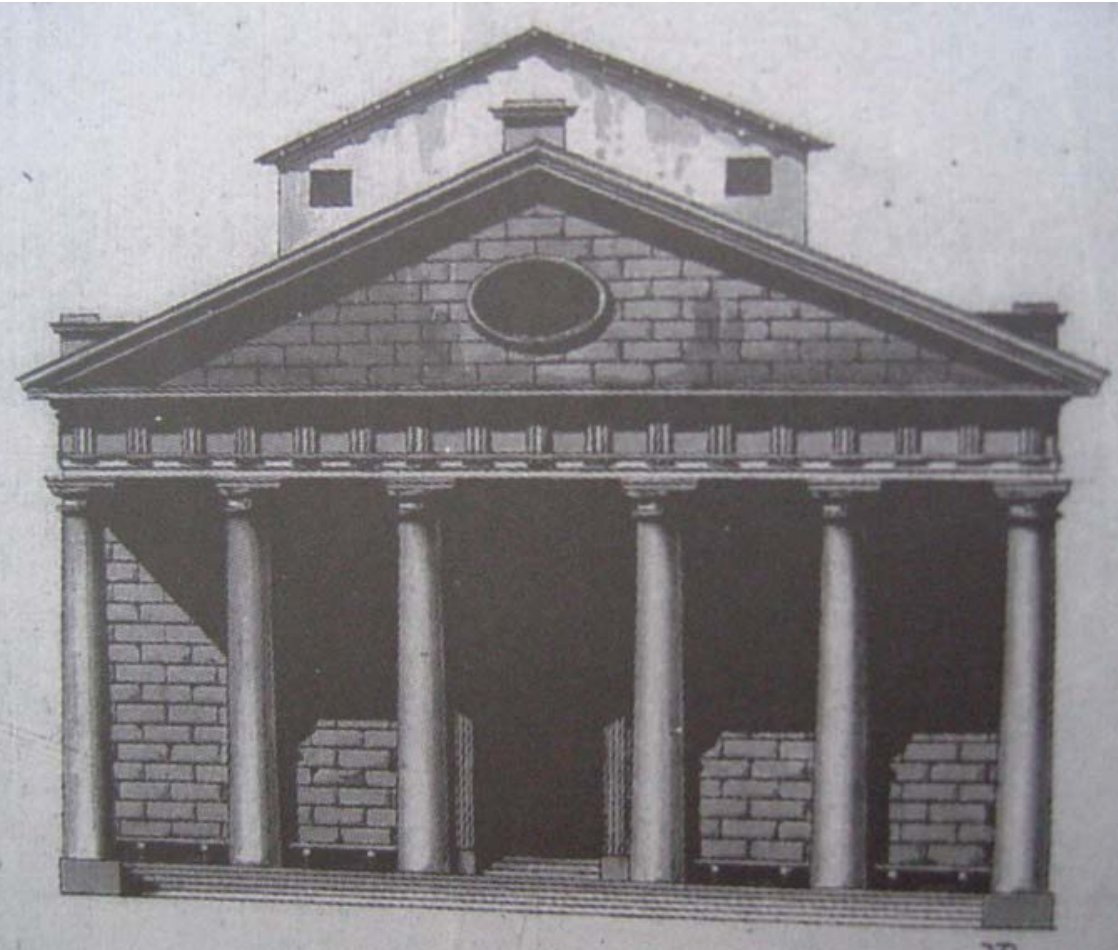

Figura 17.

Projecte per a l'església parroquial de les Preses (Garrotxa), realitzat per Eusebio M. de Ibarreche. Font: Cadiñanos 2005, 188

aprobarse el proyecto de Ibarreche. Lo que participó de acuerdo de al Academia para noticia del Consejo, y ruego a Nuestro Señor guarde su vida muchos años. Madrid siete de noviembre de mil setecientos noventa y nueve ${ }^{47}$.

Refusat el projecte d'Ibarreche, es fa una crida a l'arquitecte de la Real Academia de San Fernando o al de la Reial Acadèmia de Sant Carles de València que es trobin més pròxims al corregiment (de Girona) per tal que procedeixin a confeccionar el plànol per prosseguir l'església parroquial de les Preses ${ }^{48}$. Així doncs, l'any I 800 es cridava l'arquitecte Josep Caxant, de la Reial Acadèmia de Belles Arts de Sant Carles, de València, qui va refusar l'encàrrec. Finalment, serà l'arquitecte també de l'acadèmia valenciana, Manuel Blasco, qui enviarà un minuciós informe i un plànol que seria aprovat per l'acadèmia de Madrid l'any $1803^{49}$.

L'església actual de les Preses - pensem que resultant del projecte de Blasco - difereix força del projecte ideat per Ibarreche. Si bé, en el projecte d'aquest, el campanar tenia poca rellevància, la materialització final de la nova església de les Preses va donar lloc a una església on la façana està presidida i flanquejada al mateix temps per dos campanars de torre, que també esdevindran un element recurrent en algunes esglésies neoclàssiques construïdes a Catalunya durant el primer terç del segle XIX, com ja hem vist que era el cas de la desapareguda es-
47. AHN: Consejos. Legajos 23.362 .

48. AHN: Consejos. Legajos. 23.362 .

49. AHN: Consejos. Legajos 23.362 . 


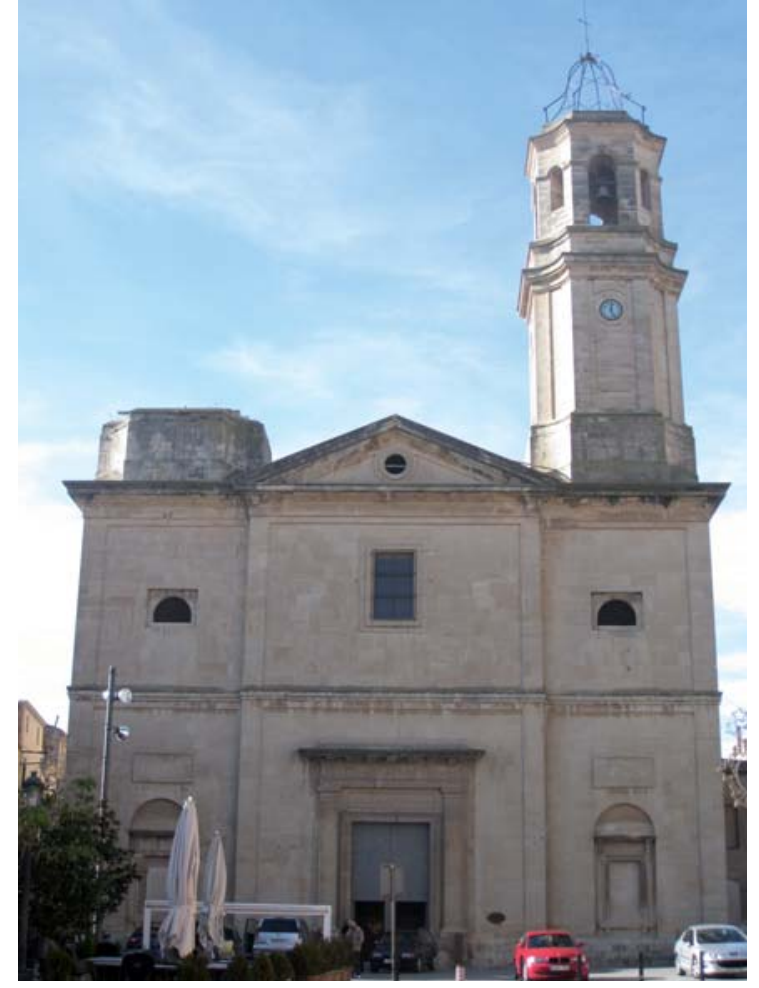

Figura 18.

Església parroquial de l’Espluga de Francolí (Conca de Barberà)

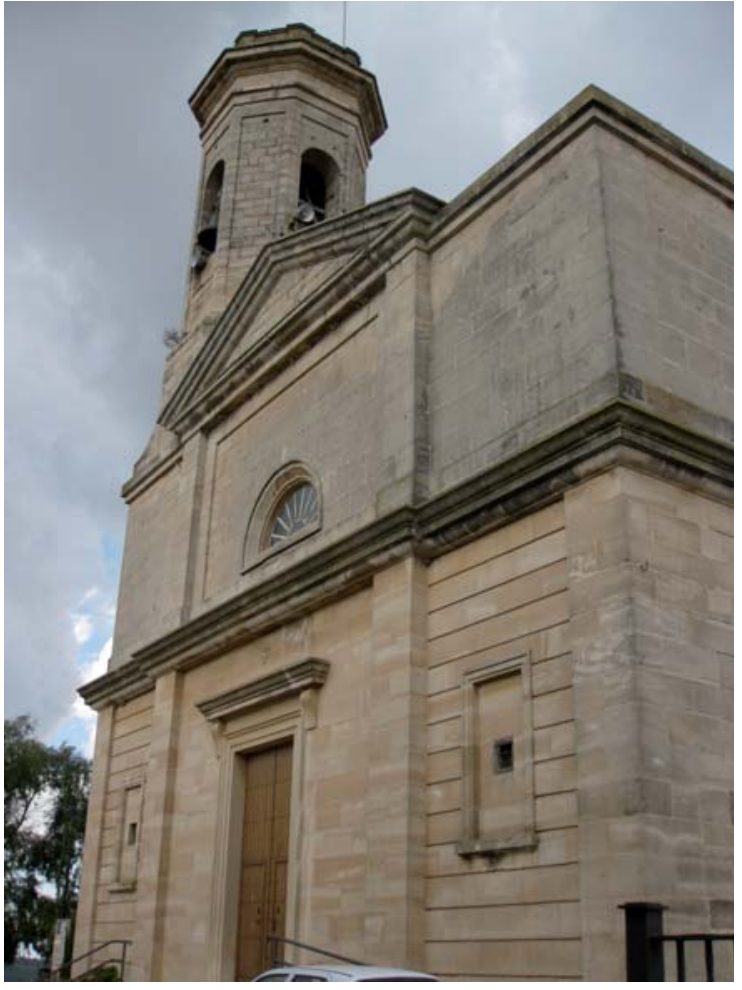

Figura 19.

Església parroquial de Belltall (Conca de Barberà).
50. RABASF: Legajos (2-335bis).

51. RABASF: Legajos (2-335bis).

52. J. Roca Armengol, Història de l'Espluga de Francolí. Segle XIX, volum v, Lleida, Pagès Editors, 2000 , p. $147-156$. glésia de Molins de Rei o de l'església de Pallejà, totes dues al Baix Llobregat, mentre que un dels dos projectes d'Antoni Cellers per a l'església del Vilosell també tenia dos campanars.

Finalment, també en l'àmbit gironí, sabem que l'any I8 I7 s'havia presentat a l'Academia de San Fernando un projecte per a l'església de Lloret de Mar, realitzat per Tomàs Soler i Ferrer, que fou rebutjat per

[...] falta de proporciones en sus alzados, de inteligencia en la coordinación de la planta, excesivos gruesos y superfluos resaltos [...] y no comptando que el interesado obtenga ninguna revalidación por las Reales Academias, la de San Fernando es de dictamen que este proyecto de primer orden debe encargarse a un profesor de mérito que con mejores conocimientos lo desempeñe $e^{50}$.

El projecte és encarregat a l'acadèmic Juan Antonio Cuervo i aprovat el 7 d'agost de i 8 i 8.

També a l'actual comarca de la Selva, l'arquitecte Francesc Vallès - a qui ja hem vist com a artífex de l'església de Molins de Rei- havia presentat, l'any I 827, un projecte per a l'ampliació i la reforma de l'església de Santa Coloma de Farners, el qual va ser aprovat per l'Acadèmia en vista «del acertado desempeño de Vallés en el arreglo de la parte antigua subsistente, como de las obras de aumento y reforma que se propone» ${ }^{51}$.
D’altra banda, ja en una data tardana i a la comarca tarragonina de la Conca de Barberà, la nova església del poble de l'Espluga de Francolí (iniciada l'any I 860) $)^{52}$, amb plànols d'Ignasi Jordà i sota la direcció de Josep Molner i Josep Mestres, donarà com a resultat una façana austera, que pretén recuperar d'alguna manera - i de forma encara més simple - les línies de la façana de la parroquial de Sants, amb la divisió en tres cossos i tester amb frontó triangular. La façana de l'església de l'Espluga de Francolí es reproduirà - si bé de forma més reduïda - a la propera població de Belltall, mentre que també a la Conca de Barberà, entre els anys I 862 i I 865 , es construirà l'església de Sant Salvador de Pira.

Però durant el primer terç del segle XIX - la cronologia que més ens interessa- es documenten nombrosos projectes de reforma, ampliació o construcció de bell nou d'esglésies parroquials tarragonines. Algun d'aquests projectes, com el de Montroig del Camp - signat pel mestre d'obres Josep Miralles l'any i 819-, fou realitzat de forma incompleta, atès que la façana principal va quedar per acabar; d'altres ni tan sols es dugueren a terme, com en el cas de Vilaseca de Solcina, per a la qual l'arquitecte Juan Antonio Cuervo havia reformat els plànols que Simó Ferrer havia fet l'any i 800 . Tampoc prosperà el projecte de Bartolomé Ribelles per a l'església d'Ulldecona, realitzat abans de i 800 però que l'any I8I 3 encara estava per fer. Final- 


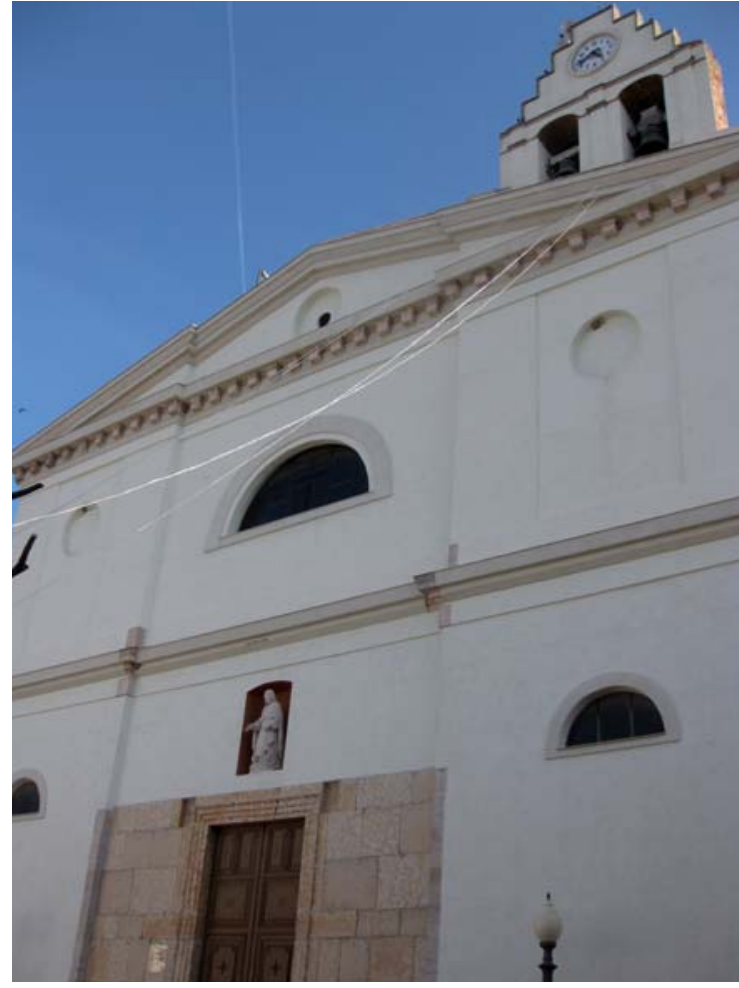

Figura 20.

Església parroquial del Masroig (Priorat).

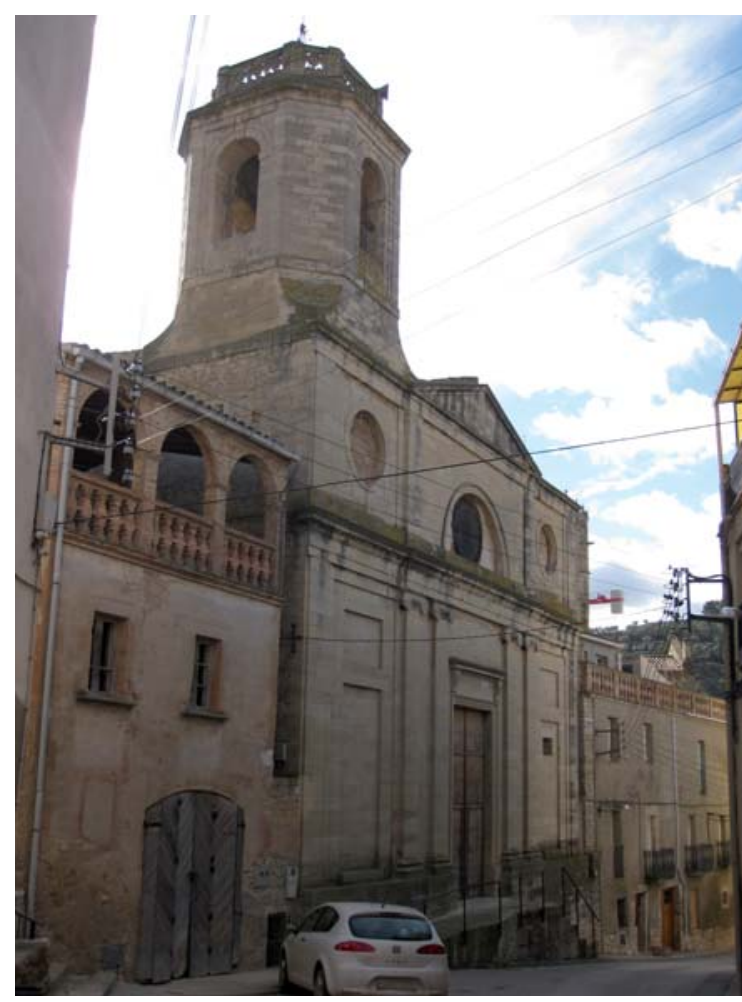

Figura 21.

Església parroquial de Vallbona de les Monges (Urgell).

També trobem un altre arquitecte barceloní, Josep Oriol Mestres, com a director de l'obra de la parroquial de Bellvís, tot i que sembla que les seves ocupacions a Barcelona li impedien atendre degudament les obres, que anaven a càrrec del mestre de cases d'Anglesola Josep Monné. La titularitat de Josep Oriol Mestres com a responsable de l'obra de Bellvís, però, fou deguda a la denúncia presentada al jutjat de Cervera pels mestres de cases de Lleida Pere Canals i Pere Calsada, que acusaven Antoni Monné de no tenir títol ni d'arquitecte ni de mestre d'obres, de manera que l'Ajuntament de Bellvís va demanar-li a l'arquitecte barceloní que assumís la direcció dels treballs d'execució, almenys de forma «oficial», mentre Monné constaria com a mestre d'obres encarregat de la construcció - tot i que, al contracte de l'obra, Monné s'expressa de la manera següent, fent valer el seu criteri respecte a com calia continuar l'església, que ja havia estat començada l'any i 804:

[...] seguir aquella mateixa idea que està començada en quan a lo interior, que son pilastrons islats ab sos bases de pedra picada, que lo seu nom propi es, vasas átiques, donanti la elevació que li correspon fins al asiento dels capitells; se operarà a las mias ideas, per ser així acordat per los S.S. del Magnífich Ajuntament i Comissionats, que será en lloch de aplicar capitells de fullatge, seran de orde de arquitec-
53. RABASF: Legajos (2-33-5). 
54. Balaguer i Salvia (1984, p. 314)

55. M. Garganté Llanes, «Arquitectura vuitcentista a l'Urgell. Alguns exemples», Urtx, 16, Tàrrega, 2003. Notícia extreta de AHCC: FN Bellpuig. Not. Josep Gili (1848).

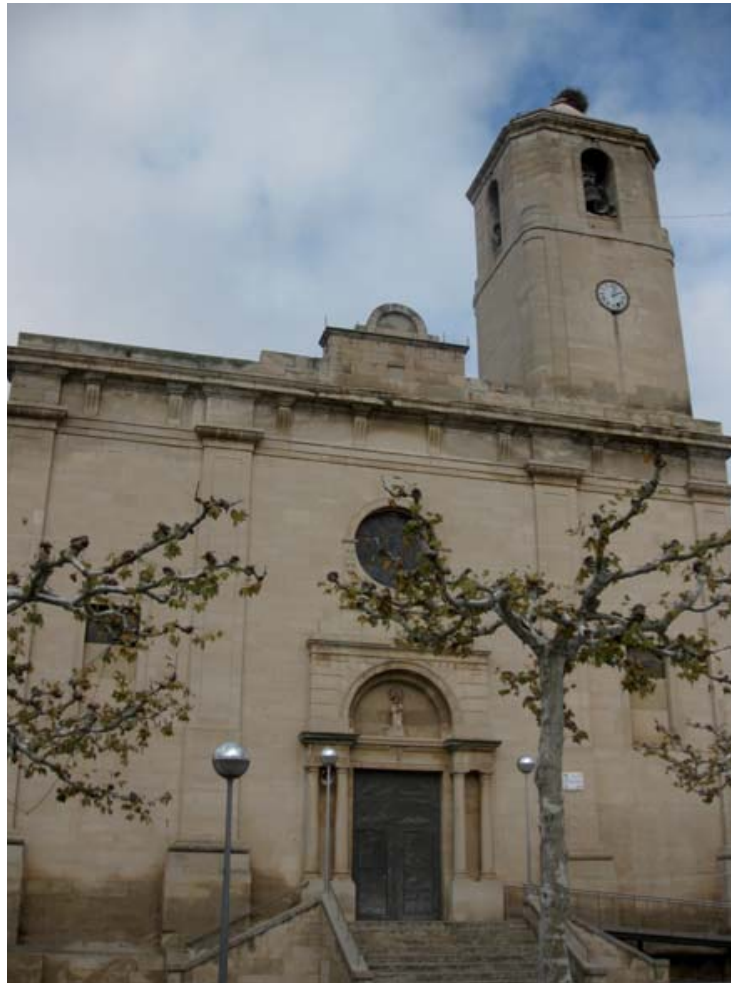

Figura 22.

Església parroquial de Bellvís (Pla d'Urgell).

tura ideal, compostos de alguns añadits, per armosejaro $[\ldots]^{54}$.

D’aquesta manera, malgrat la rellevància més gran de la figura de l'arquitecte respecte al segle XVIII, veiem com els contractes de les obres es continuen fent a favor dels mestres de cases locals, que eren els empresaris i veritables executors dels treballs $-\mathrm{i}$ que fins i tot es podien permetre certes «llicències» o variacions respecte als projectes originals. Així doncs, sabem, per exemple, que l'obra de l'església parroquial de Rocafort de Vallbona és contractada l'any I 848 per Bonaventura i Josep Palau, mestres de cases de Bellpuig ${ }^{55}$. Per fer inventari de les esglésies de la primera meitat del segle XIX, a les esglésies de Vallbona, Bellvís i Rocafort hem d'afegir-hi, si bé de moment no n'hem trobat referències documentals, les esglésies de la Figuerosa (a l'Urgell, com ara Vallbona i Rocafort) i la Foradada (Noguera).

L'examen de la documentació generada per la construcció d'aquests temples, sobretot a les zones rurals, evidencia que molts dels aspectes relacionats amb la construcció no varien gaire respecte al segle precedent: l'arrendament del vintè de les collites continua essent la via de finançament més corrent, així com la formació d'una comissió, l'obligatorietat de demanar els permisos pertinents a Madrid - permís per emprendre l'obra, permís per arrendar el vintè- $\mathrm{i}$ les llicències eclesiàstiques.

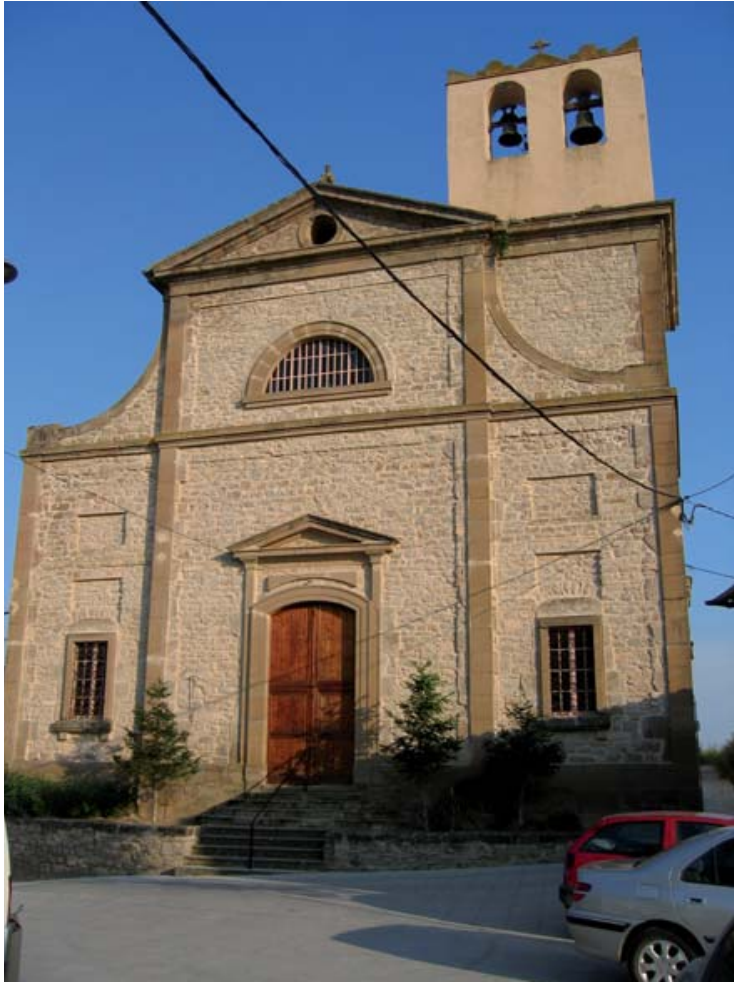

Figura 23.

Església parroquial de la Foradada (Noguera).

En definitiva, podem afirmar que l'arquitectura religiosa a les comarques de Lleida, durant la primera meitat del segle XIx, es debat entre la continuïtat de la tradició setcentista - sobretot pel que fa als interiors $\mathrm{i}$ alguns projectes ben retardataris com el de les esglésies de Sant Miquel de Lloberola, Benavent de Segrià, el Soleràs o Cervià de les Garrigues - i la renovació cap a una estètica que pretén destil.lar un cert neoclassicisme, clarament deutora de la influència de la Llotja i les obres del seu director, Antoni Cellers i Azcona.

\section{Epíleg: un llarg camí vers l'estètica neoclássica?}

El fet que difícilment podem qualificar l'arquitectura religiosa catalana d'època moderna com a barroca és quelcom ben conegut. Sembla com si l'Escola del Camp i fra Josep de la Concepció (o l'arquitectura dels ordes religiosos al nostre país) haguessin marcat una pauta ben clara per tal que ningú sucumbís a cap excés temptador. Sí que l'únic indret - sense parlar dels retaules - en el qual podem trobar algun (no gaires, però) exemple amb una certa plasticitat barroca és la façana: algun encoixinat de dovelles a saltacavall, portades amb columnes tornejades o salomòniques més o menys reeixides i coronaments que, del contingut semicercle que podríem qualificar de «serlià», passen a 
un joc més capriciós de corbes i contracorbes - sobretot en exemples de l'àmbit d'influència lleidatana, tarragonina o tortosina, on podem parlar de la suggestió aragonesa o valenciana.

La façana no fa el tot, però és l'element «de representació» de l'edifici i aquell que genera més preocupació. Així, veiem com són les façanes projectades per mestres d'obres poc destres l'element que provoca més rebuig entre els acadèmics, i com les façanes projectades pels acadèmics provoquen el rebuig del poble, més sensible a alguna «filigrana», més que no pas a la rigidesa i a l'austeritat classicistes. Aquestes mateixes preferències són les que ens expliquen que, encara a mitjan segle XvIII i més enllà, trobem decoració escultòrica de les característiques del retaule del santuari del Miracle o de la capella dels Colls a Sant Llorenç de Morunys, tots dos exemples al Solsonès -i no oblidem que serà la pervivència d'aquestes i d'altres «romanalles» les que condicionaran la reial ordre de Carles III de l'any I 777 .

Aquesta mateixa sensibilitat i «gust» farà que, per exemple, a Barberà de la Conca no s'accepti el projecte realitzat per l'acadèmic Andreu Bosch, i la realització material segueixi, en canvi, les traces d'un tal fra Tomàs, del convent franciscà de Montblanc, que remetien a les sempiternes façanes de perfil curvilini i porta abarrocada. Curiosament, també en el cas de l'església de Vacarisses s'estudiava un projecte basat en la mateixa tradició - perfil curvilini i, en aquest cas, porta que segueix el model de la ja reculada en el temps església barcelonina de Sant Felip Neri- i que serà aplicat en esglésies com ara la de Vilobí d'Onyar o la desapareguda dels agustins de Palamós (segons projectes de Francesc Soriano i Josep Renart, respectivament), amb el projecte acadèmic de Mateo Medina, amb façana de línies clàssiques, flanquejada per dos campanarets de torre coberts amb cupuletes en forma de bulb (una concessió a les reminiscències barroques de determinada arquitectura religiosa del segle xvIII, com ara la centreeuropea, i motiu que farà fortuna com a coberta de nombrosos campanars, sobretot en territori aragonès ${ }^{56}$. Poques vegades, doncs, s'imposava l'opció academicista per damunt de la més «barroca», que era la que acostumava a plaure als comissionats de l'obra. Ja hem vist anteriorment com el triomf de les opcions academicistes poden comptar-se amb els dits d'una mà: Vilallonga en seria un, i Torrefarrera, un altre.

En canvi, l'evolució i el recorregut dels interiors d'aquests temples és menys convulsa: al predomini absolut de la nau única, longitudinal i amb capelles per banda, el succeïrà la recuperació de la planta de saló, que emergeix amb força als territoris lleidatans i tarragonins - suggestió de la gran obra del Pilar de Saragossa, en primera instància, i de la construcció de la catedral de Lleida-, si bé recuperava el model de Pere Blai per a la capella de
Sant Jordi del Palau de la Generalitat, puntualment recuperat a mitjan segle XviII per a la capella de la Universitat de Cervera i l'església de Sant Miquel del Port de la Barceloneta.

Planta de saló amb tres naus i planta de nau única conviuran a finals del segle Xviı i seguiran fent-ho durant les primeres dècades del segle XIX, en un exemple de continuitat absoluta pel que fa al model espacial. És per això que, si hem de parlar d'algun canvi que ens faci qualificar l'arquitectura religiosa del primer terç del segle XIX com una arquitectura de caràcter més «clàssic» que l'anterior, hem de parlar indiscutiblement de les façanes com a element determinant del «triomf» d'un cert classicisme acadèmic. $O$ potser estaria més ben dit «neopal-ladianisme»? De fet, no es remetran a l'exemple pal·lodià d' «Il Redentore» tantes conques alsidals definides per la presència de columnes o pilastres? Seria el cas del primitiu projecte de Cellés per a l'església sabadellenca — avui molt reformada i desvirtuada en aquesta part-, del projecte de Vilanova i la Geltrú, del de El Masroig o fins i tot el retaule-baldoquí de l'església barcelonina dels Sants Just i Pastor.

Efectivament, més que exemples que puguem denominar «neoclàssics» amb tota tranquil-litat - com ara el projecte irrealitzat per a l'església de les Preses o el pòrtic de l'església desapareguda de Molins de Rei-, el que trobem és una influència que podríem qualificar de «pal-ladiana» i que ens remet fins i tot a un exemple romà del segle xvi, com seria la façana de l'església de la Trinità dei Monti, de Giacomo della Porta.

En definitiva, el mestre d'obres i professor de l'Escola d'Arquitectura de la Llotja, Francesc Renart i Arús, llegeix un discurs en la sessió literària del 8 de novembre de 1836 a l'Acadèmia de Bones Lletres, on defineix com ha de ser l'arquitectura religiosa de l'època:

Los templos son la casa de Dios: exigen por lo mismo grandiosidad, recogimiento, modestia en sus partes, de manera que unidas formen lo que llamamos augusto. Las grandes masas, las proporciones armónicas, el golpe de vista de toda la extensión natural, construiran grandioso un templo. Háyase recogido la distribución de luces practicada con economía, a tiempo, en los parages debidos y en formas convenientes. Será por fin modesto, siempre que los adornos accesorios no usurpen a la masa principal el primer puesto en la composición, ni el principal efecto a la ara o a la adoración del númen, que debe ser el primero.

Lejos pues de nuestros templos falaces apariencias en las fachadas; lejos de su interior los gruesos machones que producen un todo grave y mezquino a un tiempo, lejos la profusión inútil y dañosa de luces; lejos, en fin, la
56. CAdiñanos $(2005$, p. $172-$ 175). 
57. BNC: Fons Renart. Lligall $\mathrm{LV}, 6$.

58. Bassegoda Nonell (1974, p. 24).

59. M. Garganté Llanes, «La construcció del monestir benedictí del Miracle i el mestre d'obres Ramon Riera: aproximació al seu estudi», Oppidum, 3, Solsona, Centre d'Estudis Lacetans, 2005. errónea manía de rellenarlos todos de altares, de estátuas, de mármoles.

Sea un templo de un solo orden de majestuosas columnas en su exterior e interior; reynen en el por todas partes la sencillez y el recogimiento y unos pocos emblemas de fácil interpretación, alguna bajo relieves y algunas inscripciones formen únicamente su adorno ${ }^{57}$.

Un cop superada aquesta primera meitat del segle xIx, encavallant-se amb el segon terç del segle (I835-1868), l'arquitectura denominada «isabelina» suposarà una continuïtat del neoclassicisme, però amb l'addició d'elements romàntics que derivaran cap a formes neomedievals, especialment cap a l'estètica neogòtica - per exemple, ja hem comentat al principi com Josep Simó Fontcuberta també projectarà l'església neogòtica, avui desapareguda, de Sant Martí del Clot (alhora que ja hem vist com serà l'artífex del projecte neoromànic de Sant Feliu de Llobregat). Com assenyala Bassegoda, també seran d'aquesta època les petites vil-les de l'extraradi de Barcelona, fetes segons models de Ledoux o el propi Palladio, i posa com a exemple la torre de Craywinkel, a Sant Gervasi, o la torre Llosana, a Horta ${ }^{58}$.
A partir d'aquest moment, serà el neomedievalisme la tendència que s'imposarà entre els arquitectes barcelonins sortits de les aules de Josep Casademunt, successor de Cellers a la classe de la Llotja. Elies Rogent esdevindrà el més fervent defensor de la tradició catalana medieval, amb obres emblemàtiques com ara la restauració del monestir de Ripoll o l'edifici central de la Universitat de Barcelona (I860-187I), on recull excepcionalment la influència de l'anomenat rundbogenstil germànic, i que d'altres arquitectes com ara Francesc Daniel Molina traslladaren també a edificis com el Real Colegio Tarrasense - actual Escola Pia de Terrassa - ( I 864) o al monestir del Miracle de Riner (Solsonès), projectat pel mestre d'obres Ramon Riera ja a les acaballes del segle ${ }^{59}$.

Amb tot, ni que sigui de forma més minoritària, encara trobarem autors que, a l'últim quart del segle xIx, segueixen de manera fidel la tradició clàssica, com ara Antoni Rovira i Trias, amb el Museu Martorell de Geologia (I 878), o Jeroni Granell i Mundet, amb la Biblioteca Museu Víctor Balaguer de Vilanova i la Geltrú (I882-I884). N'esdevé un grandiós epíleg l'estudi Masriera, al barceloní carrer de Bailén i projectat per Josep Vilaseca i Casanovas com un temple clàssic. 


\section{APÈNDIX}

I

Carta d'Antoni Cellers a propòsit de l'església del Vilosell AHN: Consejos. Legajos. 37.450. Muy Magnífico Señor:

En atención al oficio que V.S. tuvo a bien dirigirme con fecha de I 2 abril último, para que segundando las órdenes del Supremo Consejo de Castilla, siendo yo académico de mérito de la Real Academia de San Fernando, pasase a ese pueblo del Velusell a encargarme de la comisión de hacer los diseños y operaciones necesarias, junto con el cálculo del coste de la iglesia parroquial que los vecinos de dicho pueblo desean construir con permiso de S.M., expondré a V.S. brevemente lo que me impone mi obligación.

El terreno escogido por los maestros del país, antes de tener yo tal encargo y al que me he sujetado por no mover disputas entre los vecinos, es infeliz, por ser muy irregular, rodeado de calles angostas, tortuosas y de mucha inclinación, lo que ocasionará muchos mayores gastos por la dificultad del transporte de los materiales, por el difícil manejo de ellos, además de resultar muy grande el coste de los cimientos y del desmedido basamento que resulta del desnivel de dichas calles; no obstante desde que tomé las medidas de dicho sitio dirigí mis miras a hacer que los diseños pudiesen executarse en dicho paraje, o en algun otro más ventajoso, con solo hacer pequeñas variaciones.

Dirijo a V.S. el fruto de mi trabajo y estudio sobre dicha obra en ocho dibujos, a saber el plano topográfico de dicho sitio, la planta de la nueva iglesia, tres fachadas y tres cortes o dibujos de lo interior de la misma.

Quando llegue el caso pondré todos los medios para que la obra sea executada con la más escrupulosa exactitud que pide el arte y a su tiempo, quando V.S. establezca haré los reconocimientos necesarios, en cuyas ocasiones se darán las instrucciones convenientes a los asentistas y se harán en grande las plantillas de todos los perfiles y de quanto convenga.

En quanto al coste de la obra, esde es de dos especies, a saber el importe de todos los materiales y jornales de las diversas artes de deben concurrir a construir la iglesia, asciende a quatrocientas quarenta y ocho mil setecientos setenta reales de vellón.

La compra de las casas y patios según la pericia hecha por los maestros del país antes de estar yo encargado de esta comisión, y a cuyos cálculos me remito asciende a quarenta y siete mil reales de vellón. Dichos patios y casas ocupan hoy día el sitio donde se trata de hacer la iglesia.

Esto es quanto debo exponer a V.S. sobre el particular a fin que pueda hacerlo presente a S.M., por medio de su Supremo Consejo de Castilla.

Dios guarde a V.S. muchos años.

Lerida 28 julio I 8 I 7. Antonio Cellés.

\section{II}

Taba per a la construcció de l'església parroquial de Sants BNC: Fons Renart. Lligall XVIII (4).

Condicions a que deuran arreglar-se la persona o personas que prengan a son càrrech la construcció de la obra que se expressa- rà en seguida en la porció de la nova iglesia que se edifica en lo lloch de Santa Maria de Sants del partit de Bacelona.

I. Deurà lo preufetista construir los dos archs, ab sos relleus, de la nau principal; los quatre archs torals del centro del crusero, també ab sos relleus; los archs de relleus dels dos testeros del mateix; las parets sobre los dos dits archs de la nau principal, que han de formar lo vertent per colllocar las vigas de la cuberta; los petxinons entre los archs torals; la cornisa en cru sobre estos y de sota la cúpula o mitja taronja; lo sòcol o rebanch sobre dita cornisa, en lo qual ha de assentar la referida cúpula; y las parets de alrededor de la mateixa sobre los archs torals fins al nivell que més avall se senyalarà del cap alt de las altras parets que, com se ha dit, se han de fer sobre los archs de la nau principal.

2. Deurà també lo preufetista pujar las parets dels costats de la nau principal sobre los archs de las capellas y las dels costats dels brassos del crusero y presbiteri tres palms, poch més o menos, en la part exterior, que seran necessaris per deixar ditas parets a la altura del cap baix de las cubertas de las expressadas nau, crusero y presbiteri; y així mateix deurà pujar los esperons o estribos dos palms y un quart, també poch més o menos en lo cap alt de ells, seguint en disminució fins al actual cap baix, y col-locant en sa part superior las canals per las ayguas que se han de conduir per esta.

3. També deurà lo preufetista pujar y deixar arregladas las parets dels dos testeros del crusero y de detrás del altar major o testero exterior del presbiteri, formant los corresponents declivis per a que las cubertas dels brassos de dit crusero y la del presbiteri, tingan igual vertent que la de la nau principal.

4. Totas las porcions que se han de pujar y deixar arregladas en las parets referidas en las condicions $2^{\mathrm{a}}$ y $3^{\mathrm{a}}$ deuran tenir respectivament los mateixos gruixos que las actuals.

5. Los archs de la nau principal y los archs torals deuran ser a punt rodó o semicirculars y de tres mahons de cap de tardossa de los que al efecte estan ja preparats y tenen un ters de palm de gruix.

6. Las parets que, com se ha dit, se han de fer sobre los dos archs de la nau principal y que han de formar los vertents per la col-locació de las bigas de la cuberta de ella, deuran ser de mamposteria y de tres palms de gruix, desgruixant-las per consegüent un quart per part des de los vius dels archs. Se ha de deixar en ellas sobre la clau de cada arch un buit o clar, de quatre palms de amplària y dos de alsada, contats estos des de la part superior dels centros de las claus, y desde esta alsada deurà arrancar un arch a punt rodó, de un mahó de cap de tardossa, de igual diàmetro que la amplària del referit buit; y las parts superiors dels centros de las claus de aquestos archs seran los caps alts de las expressadas parets.

7. Al construir-se estas y las de sobre los archs torals, deurà lo preufetista unir-las ab las altras parets dels costats de la nau principal y braços del crusero, y ab las porcions 
que se han de pujar en ellas, fent ab efecte las lligadas corresponents.

8. Al temps de fabricar-se tots los archs se faran també los archs dels relleus de tres quarts de tardossa, unint-los y lligant-los bé ab los primers, de modo que formian tots un sol cos.

9. Las cindrias dels archs se afluxarán per igual després de collats estos y se trauran ditas cíndrias quatre o cinc días després, debent emperò per això estar carregats a lo menos fins als tersos ab las parets que com se ha expressat, se han de construir sobre ells.

ı. Los petxinons entre los archs torals deuran ser macissos $\mathrm{y}$ ben lligats.

I I. La cornisa de dessota la cúpula o mitja taronja, tindrà poch més o menos tres palms y mitg de alt, y se compondrà de una faixa, un bocell y dos altras faixas, ab arreglo al motllo que se donarà.

I 2. En las parets sobre los archs torals de la part dels brassos del crusero y presbiteri, y en las parets dels testers dels mateixos, deurà deixar la preufetista a la altura y de las dimensions que se li demarcaran, los encaixos necessaris per empotrar los caps de las jasenas que han de formar las carenas de las cubertas de dits presbiteri y crusero.

I3. Tota la dita obra deurà ser ben treballada segons reglas del art: la mamposteria ben lligada y los mahons per la construcció dels archs y relleus, ben mullats, debent lo preufetista picar-los y unir-los bé en sa col-locació, gastant per esta morter ben fi y fent que los junts sian prims, com prescriu la bona edificació de semblants obras; y tot deurà ser a entera satisfacció del arquitecto director D. Francisco Renart o de la persona que es comissioni al efecte, en la inteligència de que en qualsevol cas que esta o aquell no trobian arreglada o ben construïda alguna part de obra, manaran en continent desfer-la, y per est sol manament, sens excusa ni dilació alguna, deurà lo preufetista verificar-ho y fer de nou y legalment la dita part de obra, sens que par això se li consideria ni abonia cantitat alguna de més.

I4. Per la construcció de tota la referida obra se donarán al preufetista, al peu de ella, los materials necessaris de calç, arena, guix, llambordas, reble, menudall, mahons y rajolas.

I 5 . Serà del càrrech del preufetista lo cost de tots los jornals que se empleian per dita construcció, com y també per amerar la cals, fer y refer lo morter y procurar-se la aigua necessària.

I6. També serà del càrrec del preufetista la fusta, claus y construcció de totas las cíndrias, los puntals y travessers per sostenir-las, las entenas, taulons, falcas, cordas y demés que se necessitian per lo efecte y per totas las bastidas, lo fer y desfer y los posar y traurer las ditas cíndrias, essent de la obligació del preufetista la solidesa deguada a fi de evitar tota desgracia; però se li facilitarà pera mentres duria la obra tota la fusta que té en el dia la comissió de esta, la qual deurà retornar concluida que sia la dita obra en lo mateix estat en que li serà entregada.

17. Del total preu a que quedia ajustada la obra de que se tracta, se pagarà al preufetista al fi de cada setmana una cantitat proporcionada al treball que haja fet en ella, retenint-se emperò la comissió una quarta part de esta cantitat en qualitat de fiança y concluïda enterament la expressada obra, y havent cumplert com és degut lo preufetista, se li satisfarà tot la que alcansia.

I 8. Ab estas condicions y no sens ellas, se donaran ditas per lo total de la obra referida.

Sants, 25 de març de I 823 .

III

Text explicatiu del projecte d'Antoni Cellers per a l'església dels escolapis de Sabadell, presentat a la Real Academia de San Fernando

APEPC: Sabadell, Llibre que conté els Datos relativos a la construcción de la iglesia.

Proyecto de la yglesia de Padres Escolapios de la villa de Sabadell, la cual por decreto autógrafo de 22 de enero de I 829, manda SM erigir a expensas del Real Patrimonio de Cataluña.

La irregularidad del terreno en donde debe edificarse la nueva iglesia, el no poder tener sino 57 varas de longitud en vez de 59 según el Real Decreto y el hacerla capaz para contener 500 niños a lo menos, conforme el real ánimo de S.M. y finalmente el poder dar una comunicación entre el colegio y la iglesia, motivó al arquitecto académico comisionado a hacer la misma de planta ovalada, consiguiendo por este medio el que los niños sean vistos a la vez por sus maestros y que contenga varias piezas que le son anexas.

La necesidad de dexar enteramente libre la línea de la fachada principal de dicha iglesia y la absoluta precisión de hacer entre esta y el colegio la espresada comunicación, ocasionó el tener que contar con demoler una mala puerta o paso que da entrada a la referida villa, sobre la cual hay una semi-ruinosa torre, y dentro de ella existe en cada piso una desabrigada celda para hacer pues aquella comunicación, reponer la entrada a la villa y las indicadas dos celdas se ha de hacer el pequeño cuerpo de obra $\mathrm{S}$ y a fin de ocupar el espacio irregular que estaba determinado para las oficinas de la iglesia se construirá el cuerpo de obra $\mathrm{R}$ consiguiéndose con esta disposición del todo y de sus partes el que los tales cuerpos S, R y el principal cojan solamente i 20 varas superficiales, siendo así que haciendo la iglesia con sus oficinas de 59 varas de largo, según el Real decreto, por 29 de ancho se hubiera tenido que obrar sobre una superficie de I7 I I varas; por lo cual se echa de ver que el presente proyecto será algo más que una cuarta parte de menor coste que el propuesto de 59 varas de longitud; pudiéndose además desechar con la iglesia ovalada todo el angosto terreno $\mathrm{C}$ de 22 varas que hay desde la pared testera del presbiterio hacia atrás, hasta las mencionadas 59 varas.

El arquitecto no ha hecho la iglesia circular y de un diámetro igual al mayor de la ovalada, en razón a que sobre no poderse acordar bien el paso de comunicación, las piezas 7, 8 y 9 quedaban inservibles por su pequeñez, inutilizándose asimismo el oratorio número $\mathrm{C}$.

Explicación de la Planta A o sea el plan topográfico.

I. Collegios de los PP. Escolapios. 2. Calle del Safareig. 3. Carretera de Barcelona. 4. Entrada a la villa de Sabadell. 5. Cuadra. Sobre esta y la entrada hay un torreón. 6. Ronda para los carros. 7. Calle San Juan. 8. Terreno servible para edificar la iglesia y las oficinas, habiéndose dejado porción del de atrás, señalado con la letra $\mathrm{C}$ porque ha angostado mucho. 9. Calle del Pedregal. ıо. Campiña. 
Explicación de la planta B.

I. Entrada o sota coro. 2. Iglesia. 3. Trasteros, uno con escalerilla para subir a la tribuna. 4. Escalera por la cual los Padres Escolapios mediante el paso (señalado con líneas de puntos y con letras situado a la respectiva altura, irán desde la iglesia al colegio y demás piezas de aquella. 5. Sacristía, sobre la cual podría haber otra tribuna. 6. Pequeño oratorio para prepararse los padres antes de la Santa Misa. 7. Pieza retirada para confesar mensualmente alos niños. 8. Corredor y pieza de paso. 9. Piezas en donde los Padres Escolapios, insiguiendo su instituto reúnen por clases a los niños en los días festivos para hacerles rezar y cantar e instruirles en las máximas de nuestra Santa Religión, muchísimo antes de hacerlos oir el sacrificio de la Santa Misa y demás exercicios y platicas cristianos. io. Entrada a la villa. i I. Colegio de los Padres en cuyo piso bajo se hallan más angustiadas y húmedas escuelas y una pequeñísima iglesia; y en el piso principal estan situadas las oficinas de cocina, dispensa y refectorio y un corto número de celdas, estando las restantes al piso 2 medio aguardillado.

Nota: El sencillo y pequeño campanario se pondrá sobre la pared posterior de la iglesia.

\section{IV}

Relació de l'arquitecte Manuel Blasco, director de la Reial Acadèmia de Sant Carles de València concernent a l'església de Sant Pere de les Preses

AHN: Consejos. Legajos. 23.362.

El infra firmado Arquitecto Teniente Director de la Real Academia de San Carlos, en cumplimiento del encargo que se ha servido conferirme el Muy Ilustre Governador político y militar de la ciudad de Gerona, a proporción de la citada Real Academia, para que (según lo dispuesto por el Supremo Consejo en su Real Provisión de I9 de abril de I797 y el dictamen de la Real Academia de San Fernando de is de marzo del mismo año) pasase al lugar de San Pedro de las Presas en el Principado de Cataluña a formar un nuevo proyecto de iglesia parroquial para el mismo, aprovechando lo que se pueda de la obra que se halla executada para el mismo fin, me he constituído en el expresado lugar, y he tomado todos los conocimientos y medidas conducentes para el acierto, con cuyos datos he formado el adjunto proyecto dividido en cinco distintas láminas, las quales y sus explicaciones manifiestan la situación y planta de la porción de iglesia construída y la parte de obra que se halla principiada para su acrescentamiento; y así mismo el buque, disposición y decoración que tendrá según el nuevo proyecto, son sugestión a lo que permite el terreno, y a lo que puede aprovecharse buenamente de la obra ya executada, cuyas qualidades, y methodo de construcción aclara más la relación siguiente.

Primeramente es de advertir que la porción de iglesia que se halla construída se reduce a un crucero mal decorado y peor trabajado su enlucido, siendo al mismo tiempo de proporción baxa respecto al ancho de la nave, cuyas circunstancias no deven governar para que, a fin de aprovechar en un todo la obra hecha, haya de sujetarse la hacedera a las mismas proporciones y decoración de aquella, mayormente quando a poc costa pueden elevarse los quatro arcos con sus bóvedas lo suficiente para que resulte mejor proporción entre el alto y el ancho y largo que tendrá la nave de la iglesia, sin tener que subir las paredes más de lo que actualmente tienen, excepto las que han de formar el quadrado sobre los nuevos arcos torales para cubrir la cúpula, las quales, aunque han de elevarse algun tanto, no por esto aumentarán el peso a los machones, en atención a que vendrà a equilibrarse dicho peso con el que se les quitarà a las mismas paredes con motivo de la mayor elevación que se les dará a los referidos arcos, consiguiéndose por dicha elevación el poder decorar la iglesia por lo interior con un orden de arquitectura que sea algo grandioso.

Baxo de estos principios he proyectado la nueva obra para acrescentamiento de la iglesia, aprovechando de la ya executada todas sus paredes y las que para el mismo fin se hallan principiadas, como unos doce años ha, y las dexaron a la altura de veinte pamos con alguna diferencia y para ello ha sido preciso trasladar el presbiterio que en el día está a la parte de levante, al brazo de crucero que mira al medio dío, el qual por su poca capacidad exige sacar la pared que le cierra hasta alinearla con la de la sacristía, que mira hacia la misma parte, con lo que no se perjudicarà a los vecinos, por ser terreno propio de la misma iglesia, resultando por el mismo hecho que esta tenga su puerta principal en la plaza del lugar, que es lo más propio, y así mismo que su capacidad sea suficiente para novecientas personas, que es el número de almas de comunión, de que consta la feligresía; que haya capilla de comunión al lado del presbiterio y por último que se haya podido proporcionar un pórtico exterior y dos interiores en la fachada para la debida decencia del templo, cuyas partes unidas a las demás comprehendidas en la planta componen un todo en figura y superficie, como el que va delineado y lavado con una media tinta de color obscuro en la figura primera de la làmina $\mathrm{I}^{\mathrm{a}}$, sin que los vecinos sientan más perjuicio que el que resulta de privar a la casa $\mathrm{n}^{\circ}$ i 8 de la misma figura del corto espacio triangular señalado con la letra $C$, el qual deberá servir de calle para dar entrada y salida a las casas $n^{\circ}$ i 6 y i 7 .

Quanto queda insinuado respeto al aprovechamiento de la obra ya executada, como también la que se le ha de agregar de nuevo para que la iglesia tenga la capacidad competente sin que carezca de solidez, comodidad y decoro que deben acompañar a semejantes edificios, va expresado en la figura $3^{\text {a }}$ làmina $\mathrm{II}^{\mathrm{a}}$, en la qual se ve el crucero $\mathrm{n}^{\mathrm{o}}$ i I formado con las mismas paredes antiguas y sus dos brazos señalados con el $n^{\circ}$ i 2, la capilla mayor $n^{\circ}$ I 4 con su altar y credencias, la sacristía misma que en el día tiene notada con el $\mathrm{n}^{\circ} 2 \mathrm{I}$, sobre la qual ha de construirse el archivo, que tendrá su escalera nueva $n^{\circ} 24$; la capilla de comunión con su altar colocada al $n^{\circ}$ i 9 ; la nave de la iglesia ${ }^{\circ}$ 8, cuyo largo será duplo de su hancho, y los dos peristilos de ambos lados de la misma para su mayor desahogo, señalados con el $\mathrm{n}^{\circ}$ 9, cada uno de los quales tendrá tres altares que van notados con el $n^{\circ}$ io; y últimamente el pórtico exterior $n^{\circ} 2$ en donde concurren las tres puertas de la iglesia, esto es, la principal $n^{\circ} 3$, y las dos pequeñas $n^{\circ} 4$ con sus pórticos interiores $n^{\circ} 5$ en los quales estan colocadas la pila baptismal n $n^{\circ} 6$ y la escalera $\mathrm{n}^{\circ} 7$, por la que se subirá a los dos campaniles que estarán sobre aquellos sirviendo el uno para el relox y el otro para las campanas de tocar a los Divinos Oficios.

En las figuras $4^{\mathrm{a}}$ Làmina III ${ }^{\mathrm{a}}$ y $5^{\mathrm{a}}$ Làmina IV $^{\mathrm{a}}$ se ve con más claridad la decoración interior de la iglesia en donde se observarà no haver más orden de arquitectura que el dórico con modillones, y por lo mismo no van delineadas sus molduras en escala mayor, siendo fácil arreglarlas a las del autor Viñola, pues hasta los altares de ambos peristilos no tienen otro entablamento que 
las molduras mismas del capitel del expresado orden, segun se manifiesta en la figura $7^{\mathrm{a}}$ làmina $\mathrm{V}^{\mathrm{a}}$, y por lo tocante a todo el moldurage de las demás partes que componen la misma decoración sin estar sujetas a orden alguno de arquitectura, y las que componen el aspecto exterior de toda la obra, unas y otras le tienen muy perceptible en la misma làmina $\mathrm{V}^{\mathrm{a}}$ señaladas las figuras con las letras minúsculas del abecedario según el orden siguiente.

Para la decoración de la fachada figura $6^{\mathrm{a}}$ làmina $\mathrm{IV}^{\mathrm{a}}$ se arreglarán las molduras del entablamento principal a la de la figura letra A, cuya cornisa correrá por lo exterior de toda la iglesia a una misma altura, reduciendo su vuelo y omitiendo el taloncito recto, segun lo delineado en la figura letra B: las de la imposta y archivolta del arco que cubre el pórtico exterior se sujetarán a la figura letra $\mathrm{C}$, teniendo presente que la misma imposta ha de correr por dentro del mismo pórtico, y por baxo de las bocas = texas de las cubiertas de los peristilos hasta encontrar con lo exterior de las paredes del crucero: las del arquitrave, friso y cornisa del ornato de la puerta principal se dispondran según las de la figura letra D: las de la cornisa de los campaniles irán sugetas a la figura letra E: las de la imposta y archivoltas de los mismos, a las de la figura letra F; y las de la cornisa de lo exterior de la cúpula, a lo delineado en la figura letra G. Las molduras de todo lo que en lo interior de la obrano está sujeto al orden dórico se arreglaran a lo dispuesto en las figuras comprehendidas desde la de la letra $\mathrm{H}$ hasta la $\mathrm{Z}$, esto es, las de la figura letra $\mathrm{H}$ servirán para la cornisa de lo interior de la cúpula: las de la letra I para los grandes requadros mixtilíneos de la bóveda de la nave de la iglesia: las de la letra J para las archivoltas de las ventanas que hay en los lunetos: las de la letra $\mathrm{K}$ para las ventanas de los brazos del crucero: las de la letra L para el marco del quadro de San Pedro, titular de esta iglesia: las de la figura letra M para las que tiene el pedestal sobre que está plantado el referido marco: las de la figura $\mathrm{N}$ son para guarnecer las puertas que se ven en el presbiterio y crucero: las de la letra $\mathrm{O}$ para la imposta y archivolta de los altares del mismo crucero destinados el uno para el Santísimo Christo y el otro para Nuestra Señora del Rosario: las de la letra P para las impostas y archivoltas de los altares de ambos peristilos: las de la Q para las cornisitas de las dos credencias: las molduras de todas las mesas de los altares, excepto el Mayor se arreglarán a las de las figuras letra R: las de la mesa de este último van delineadas en las tres figuras señaladas con la letra $S$, así por vista como por dos secciones, una por el centro de la mesa, y otra por entre dos de sus ménsulas pareadas: y las del tabernáculo para custodia del Santísimo Sacramento se dispondrán segun las de la figura letra T: y ultimamente se han dispuesto las molduras para decorar la capilla de Comunión, delineada por cortes a lo largo y a través de su planta en las figuras $8^{\mathrm{a}}$ y $9^{\mathrm{a}}$, en las que estan señaladas con las letras U, X y Z, la primera para la cornisa de la capilla, la segunda para el marco del quadro de su altar, y la última para el tabernáculo de la misma: y por lo tocante a la archivolta de dicho altar y a las de las ventanas de esta capilla se procurarà que sus molduras vayan arregladas a las de las ventanas de la nave de la iglesia y a las de las archivoltas de los altares del crucero respectivamente, proporcionándolas a la misma razón que hay entre los todos de estas y aquellas.

Siendo otra de las partes que contribuyen a la solidez de la obra la elección de los materiales y el modo de emplearlos, particularmente en la de este proyecto en el qual media la circunstancia de haver de unir la obra nueva con la ya executada, atendiendo a la posible economía y a fin de conseguir esta sin faltar la solidez competente, soy de dictamen que en ella se empleen de varias especies según el destino que hayan que tener, esto es, mampostería ordinaria, piedra labrada, piedra solamente devastada y esquadreada, mampostería ordinaria con mezcla de ladrillo y obra de ladrillo y yeso y mampostería de ladrillo.

La mampostería ordinaria se dividirá en dos calidades, una que es la regular, cuya argamasa de distribuye con la paleta, y otra en la que se emplea la misma argamasa con lechadas, y de esta última se empleará en los cimientos, después de haber abierto sus zanjas, dándolas una quarta parte más de ancho por cada lado, que lo que tengan de espesor las paredes que hayan de cargar sobre los mismos, y haverlas profundizado hasta encontrar el terreno firme, en el qual se han de dexar bien de nivel unas con otras y cada una de por sí a lo largo y al través, teniendo presente al tiempo de la demarcación de las mismas, que los cimientos han de correr por todos los claros de las puertas y de los intercolumnios de los peristilos, como también por los vacíos que hay entre las columnas de estos y los estribos que van unidos a las paredes laterales y por baxo del graderío del pórtico exterior, y así mismo se procurarà que la zarpa de cada estribo en la parte de fuera de la iglesia sea de una vara castellana.

Para la construcción de los cimientos con la expresada mampostería se principiarà arreglando en el suelo de las zanjas una tonga de piedras llamadas comunmente carretales por su magnitud, que cuajen todo el ancho de aquellas, luego se llenarán con lechadas de argamasa de la mejor calidad todos los huecos que resulten entre las piedras y entre estas y el terreno, y se macizarán con piedra menuda a fuerza de pisón hasta que dicha primer tonga quede enteramente unida y hecha una sola pieza. Sobre la referida tonga se arreglarà otra de la misma clase y magnitud de piedras, cuidando de que sieten bien y a trava = junta con las de baxo, luego se macizarán todas las juntas irregulares y los vacíos que resulten entre las piedras y entre estas y el terreno cortado con las mismas lechadas de argamasa y piedra menuda que se dixo de la tonga primera, con la precaución de que las lechadas de argamasa han de ser más o menos claras, según lo exijan la rareza y estrechez de las cavidades; y siguiendo este mismo método se macizarán todas las zanjas hasta medio palmo antes de llegar al asiento del zócalo exterior, en cuyo estado se dexarán los cimientos de las paredes que cierran el buque de la iglesia bien igualados y nivelados, para trazar sobre ellos el zócalo referido, que ha de ser de piedra labrada a soga y tizón sentada a lecho y trabazonada con la mampostería de los cimientos que continuarán por la parte interior siguiendo el método sobre dicho hasta medio palmo antes de llegar al piso de la nave de la iglesia, en cuyo punto de dexarán todos bien castigados iguales, y de nivel, para trazar sobre ellos la obra nueva con arreglo a la planta figura $3^{\text {a }}$ làmina $\mathrm{II}^{\mathrm{a}}$.

Trazada la obra sobre los cimientos, se procederá a su construcción empleando la piedra labrada en todos los zócalos; en las basas de columnas y pilastras; en todas las gradas; en la porción de fachada más avanzada y en el ornato de la puerta principal; en los mayores resaltos y molduras de la misma fachada, y de las porciones de flancos sobre que cargan los campaniles; y por último en las cornisas de estos, y en los jarros que estan plantados sobre las cupulillas.

La piedra solamente devastada pero bien esquadreada se empleará en las losas de que se ha de forjar el mayor vuelo de la 
cornisa interior de la iglesia, en las quales han de estar vaciados los espacios que median entre los modillones, para que estos esten unidos a las mismas; también se empleará en los fustes y capiteles de las columnas de los peristilos; en los estribos que tienen correspondencia con ellas procurando que tengan labrados los paramentos que miran hacia fuera del edificio, y que en ambos lados de cada uno haya las adarajas correspondientes para trabazonarlos con las paredes que cierran los espacios en entre los mismos; y últimamente en quatro dinteles que ha de haber en lugar de arcos en los dos intercolumnios inmediatos al crucero uno en cada peristilo y en el cerramiento de los espacios de entre los estribos que corresponden a los sobredichos intercolumnios.

La mamposteria ordinaria, que se dixo ser la regular que se emplea en las paredes servirá para la continuación de las que se hallan ya principiadas entre los mencionados estribos y para la construcción íntegra de las que restan entre los mismos y van unidas a los pórticos interiores en ambos peristilos, procurando castigarla quando sea posible.

La mampostería de ladrillo se empleará en todo lo que en la fachada no ha de construirse de piedra labrada; en los macizos que resultan entre las tres puertas que dan comunicación desde los pórticos a la nave de la iglesia y a sus peristilos, los quales se construiran de esta especie de obra hasta enrasar con los arcos de las mismas puertas; y de los expresados materiales seran los campaniles, las paredes que estan sobre los arcos torales para cubrir la cúpula y las porciones de pared que acompañan a los arcos botareles; con la prevención de que los lechos de argamasa tengan poco grueso y el ladrillo vaya bien castigado, procurando amolarle las partes que hayan de estar a la vista, así en la fachada y sus campaniles, como en las porciones que acompañan a los arcos botareles, y en las paredes que de la cubierta de la cúpula para que de este modo queden os paramentos exteriores de dichas partes de edificio bien tersas y perfiladas, sin necesidad de revocarlas.

La obra de ladrillo y yeso servirà para mazizar las bocas de las capillas existentes y para hacer todas las variaciones necesarias en las paredes actuales; también se empleará en la construcción de todos los arcos y en la formación del buque de la escalera que ha de subir desde la sacristía al archivo, teniendo presente al tiempo de formar los arcos adintelados que ha de haver de columna a columna y de estribo a estribo de los peristilos (excepto en los inmediatos al crucero que serán dinteles de piedra solamente desbastada segun se dixo) que ha los primeros se les ha de dar toda la altura comprehendida en arquitrave y friso y la parte de cornisa que hay antes de llegar al asiento de los modillones y a los que corren de estribo a estribo una vara castellana, y esta misma altura o rosca se dará a los quatro arcos del crucero y a los adintelados de las puertas de sacristía y capilla de comunión; y por último se darán dos palmos a los arcos de medio punto de las puertas que hay en los pórticos interiores, a los de las ventanas de los lunetos y a los que han de hacerse ocultos sobre los quatro dinteles de piedra desvastada que ha de haver en los intercolumnios de los peristilos arriba citados; y tres palmos a los de las ventanas del crucero y a los botareles.

Todas las restantes paredes, como son la del altar mayor; los dos que cierran la capilla de Comunión por el medio día y poniente; la que cierra el uno de los brazos del crucero y la que ha de continuarse sobre las tres puertas de entrada a la iglesia desde los pórticos; y así mismo las que formarán el archivo que ha de estar sobre la sacristía se construyan de mampostería ordinaria encaxonada con pilares y faxas de ladrillo, procurando que todos los ángulos, brancas de puertas y ventanas, las pilastras de la pared que cierra el brazo del crucero, y las columnas embebidas del altar mayor sean de ladrillo y sirvan de pilares, con los quales se han de unir las faxas horizontales de quatro hiladas de lo mismo que se repartirán en la altura de las paredes de seis en seis palmos castellanos con corta diferencia; y de esta misma estructura se formarán todas las mesas de los altares.

Las bóvedas se fabricarán todas de tabique doble y los encarreronados de sobre las mismas se haran de tabique sencillo, y todas las faxas con molduras que circuyen la iglesia por lo exterior de nivel con la cornisa de la fachada y con la imposta de la misma, como también la cornisa de la parte exterior de la cúpula del crucero se formarán de ladrillo bien cortado y amolado.

Y por último se enlucirá interiormente con yeso toda la obra, arreglándose a lo diseñado en los cortes a lo largo y al través de la misma, excepto las partes que se ha dicho que han de ser de piedra labrada procurando que esté todo bien trabajado: a fin de evitar gasto y prolijidad que ocasionan los estucos, soy de parecer que después de enlucida la obra, y que esté bien enjuta se distingan todas las partes que componen su decoración dándola de tres medias tintas bien acordadas, sin emplear más oro que en los dos tabernáculos, en la guarnición de quadro del titular San Pedro Apóstol, y en el poco adorno que tienen los altares, que también será de yeso; no empleando más madera en todo el edificio que la que se necesite para la construcción de los mencionados tabernáculos y balaustrada de la capilla de comunión, como también para la carpintería de puertas y ventanas y para las soleras, que hay sobre las puertas menores del pórtico exterior para separarlas de la rejas que tienen encima y otra que ha de haver por baxo los arranques del arco apuntado que se ve en el corte a lo largo de la iglesia Làmina III ${ }^{\mathrm{a}}$ sobre la bóveda de dicho pórtico; y asi mismo la que se necesitará para el piso y cubierta del archivo y para el piso de campanas en ambos campaniles: para todo lo qual será a propósito la madera que saldrá de la cubierta de la porción de iglesia que se halla executada.

Construyéndose esta obra con arreglo al presente proyecto, he calculado su costo por menor, con separación de los distintos géneros de estructura arriba expresados, atendiendo a los precios de los materiales y jornales en aquel país, y ha resultado por su total importe la cantidad de diez y siete mil, setecientos veynte y dos pesos, cinco reales y veinte y siete maravedíes de moneda castellana, según es de ver en el siguiente [...].

\section{V}

Expedient per a la construcció de la nova façana de l'església parroquial d'Olost, segons el disseny de Francesc Daniel Molina

RABASJ: Expedients. No I 3. Resolt a 3 I d'agost de i 85 I. Projecte presentat el in d'agost.

Expediente sobre el proyecto de fachada de la iglesia de Olost, diocesi de Vich, presentado para la aprobación por D. Francisco Daniel Molina

El infraescrito arquitecto aprobado por la Real Academia de Nobles Artes de San Fernando, tiene el honor de manifestar a V.S.: Que a invitación del Reverendo Cura Párroco y obreros de la iglesia parroquial del pueblo de Olost en el obispado de 
Vich, ha pasado a formar el diseño de la fachada principal de dicha iglesia, que presenta a V.S. para el debido examen y aprobación.

Los escasos caudales que hay disponibles para la ejecución de esta obra, la limitación de las alturas correspondientes al interior del edificio, el orden arquitectónico adoptado en la decoración de la iglesia, y la precisa condición de seguir las naves laterales, no siendo poder adelantar la nueva fachada por ser sumamente angostas las calles que rodean dicha iglesia; han sido motivos poderosos de no poder estender sus ideas como hubiera sido de desear, y cual se requiere en obras de esta naturaleza.

La fachada cuyo diseño se acompaña deberá levantarse parte de ella, sobre los cimientos que tenía la antigua que fue devorada por las llamas: Elévase sobre el zócalo que le sirve de basamento cuatro pilastras con su correspondiente cornisamento del orden compuesto, cuya altura y proporciones son las que decoran la parte interior del templo: en su remate que lo forma un ático se coloca una abertura semicircular destinada a recibir la luz y ventilación tan esencialmente recomendada en esta clase de edificios.

El hueco que forman las escaleras de los dos campanarios señalados en el plano con los números i y 2 , el primero sirve para la colocación de la pila bautismal, y el segundo para trasteras o a los usos que más convengan.

Tales son los pies forzados a que precisamente ha devido sugetarse el proyecto que se acompaña, el cual si mereciese la superior aprobación de este cuerpo científico se pasaría desde luego a su ejecución.

Dios Guarde a V. S.

Barcelona I 5 de agosto de I 85 I Francisco Daniel Molina. 